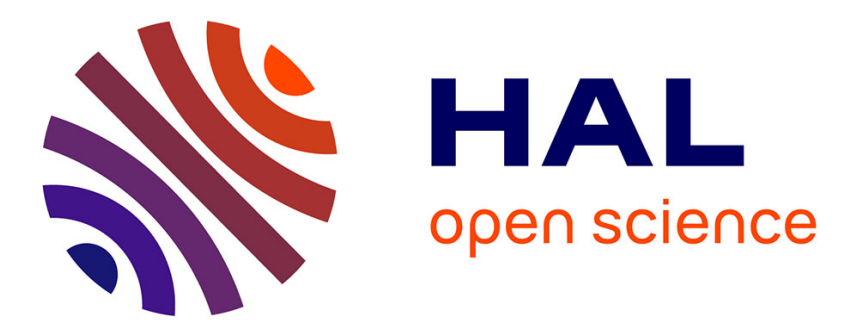

\title{
Mantle refertilization and magmatism in old orogenic regions: The role of late-orogenic pyroxenites
}

Lydéric France, Gilles Chazot, Jacques Kornprobst, Luigi Dallai, Riccardo Vannucci, Michel Grégoire, Hervé Bertrand, Pierre Boivin

\section{- To cite this version:}

Lydéric France, Gilles Chazot, Jacques Kornprobst, Luigi Dallai, Riccardo Vannucci, et al.. Mantle refertilization and magmatism in old orogenic regions: The role of late-orogenic pyroxenites. Lithos, 2015, 232, pp.49-75. 10.1016/j.lithos.2015.05.017 . insu-01185449

HAL Id: insu-01185449

https://hal-insu.archives-ouvertes.fr/insu-01185449

Submitted on 7 Dec 2019

HAL is a multi-disciplinary open access archive for the deposit and dissemination of scientific research documents, whether they are published or not. The documents may come from teaching and research institutions in France or abroad, or from public or private research centers.
L'archive ouverte pluridisciplinaire HAL, est destinée au dépôt et à la diffusion de documents scientifiques de niveau recherche, publiés ou non, émanant des établissements d'enseignement et de recherche français ou étrangers, des laboratoires publics ou privés. 
4 Lydéric FRANCE $^{1 *}$, Gilles CHAZOT $^{2,3}$, Jacques KORNPROBST ${ }^{4}$, Luigi

5 DALLAI $^{5}$, Riccardo VANNUCCI ${ }^{6}$, Michel GREGOIRE ${ }^{7}$, Hervé BERTRAND $^{8}$,

6 Pierre BOIVIN ${ }^{4,9,10}$

7

1: CRPG, UMR 7358, CNRS, Université de Lorraine, Vandœuvre-lès-Nancy, France

2: Université Européenne de Bretagne, France

3: Université de Brest ; CNRS ; UMR 6538 Domaines Océaniques; Institut Universitaire Européen de la Mer, Place Copernic, 29280 Plouzané, France

4: Clermont Université, Université Blaise Pascal, Laboratoire Magmas et Volcans, BP 10448, F-63000

Clermont-Ferrand, France

5: Istituto di Geoscienze e Georisorse (IGG), CNR, via Moruzzi 1, 56124 Pisa, Italia

6: Dipartimento di Scienze della Terra, Università di Pavia, via Ferrata 1, 27100 Pavia, Italia

7: Géosciences Environnement Toulouse, (GET, UMR 5563), Observatoire Midi-Pyrénées, 14 avenue E. Belin, 31400 Toulouse, France

8: Laboratoire de Géologie de Lyon, UMR-CNRS 5570, ENS Lyon et Université Lyon1, 46 Allée d'Italie, 69364 Lyon cedex 07, France

9: CNRS, UMR 6524, LMV, F-63038 Clermont-Ferrand, France

10: IRD, R 163, LMV, F-63038 Clermont-Ferrand, France

*Corresponding author: 1yde@crpg.cnrs-nancy.fr

Keywords: pyroxenite, mantle, cumulate, xenolith, metamorphic petrology, garnet, oxygen isotopes, eclogite, sapphirine, P-T conditions, Morocco, Jordan, Cameroon, French Massif-

Central 
27 Abstract

28 Pyroxenites and garnet pyroxenites are mantle heterogeneities characterized by a lower solidus temperature than the enclosing peridotites; it follows that they are preferentially involved during magma genesis. Constraining their origin, composition, and the interactions

31 they underwent during their subsequent evolution is therefore essential to discuss the sources

32 of magmatism in a given area. Pyroxenites could represent either recycling of crustal rocks in

33 mantle domains or mantle originated rocks (formed either by olivine consuming melt-rock reactions or by crystal fractionation). Petrological and geochemical (major and trace elements, $\mathrm{Sr}-\mathrm{Nd}$ and $\mathrm{O}$ isotopes) features of xenoliths from various occurrences (French Massif-Central, Jordan, Morocco and Cameroon) show that these samples represent cumulates crystallized during melt percolation at mantle conditions. They formed in mantle domains at pressures of 1-2 GPa during post-collisional magmatism (possibly Hercynian for the French MassifCentral, and Panafrican for Morocco, Jordan and Cameroon). The thermal re-equilibration of lithospheric domains, typical of the late orogenic exhumation stages, is also recorded by the samples. Most of the samples display a metasomatic overprint that may be either inherited or likely linked to the recent volcanic activity that occurred in the investigated regions. The crystallization of pyroxenites during late orogenic events has implications for the subsequent evolution of the mantle domains. The presence of large amounts of mantle pyroxenites in old orogenic regions indeed imparts peculiar physical and chemical characteristics to these domains. Among others, the global solidus temperature of the whole lithospheric domain will be lowered; in turn, this implies that old orogenic regions are refertilized zones where magmatic activity would be enhanced. 


\section{Introduction}

The shallowest part of the Earth's upper mantle is made primarily of peridotite, with spinel lherzolite and harzburgite being the most abundant lithologies. Pyroxenites and eclogites represent less than two percent of the upper mantle according to estimations based on isotopic considerations (Pertermann and Hirschmann, 2003), or up to five percent considering estimations made in orogenic peridotite massifs (e.g., Kornprobst, 1969; Pearson et al., 1993). Although they represent only a small volume of the upper mantle, pyroxenites and eclogites provide important information about dynamic processes occurring since the formation of the Earth, and about crustal recycling and melt circulation through the mantle (e.g., Downes, 2007; Gonzaga et al., 2010a). Due to their fertile composition and low solidus temperature compared to the host mantle peridotites, pyroxenites are quite relevant during mantle partial melting and basaltic magma genesis (Hirschmann and Stolper, 1996; Lambart et al., 2009). Their role in basalt genesis has indeed been inferred in oceanic and continental settings (e.g., Sobolev et al., 2005; Heinonen et al., 2013).

The origin of pyroxenites (as well as eclogites) found in mantle bodies or in mantle xenoliths is highly debated. They can represent dehydrated or residual and partially molten crustal lithologies recycled into the upper mantle through subduction zones (e.g., Allègre and Turcotte, 1986; Viljoen et al., 2005; Gonzaga et al., 2010a; Montanini et al., 2012). Such mantle heterogeneities usually display a greater variability in chemical and isotopic compositions compared to peridotitic mantle (e.g., Gonzaga et al., 2010a, b). Pyroxenites can also represent high-pressure cumulates fractionated from basaltic magmas circulating through the upper mantle (O’Hara and Yoder, 1967; Viljoen et al., 2005; Downes, 2007; Gonzaga et al., 2010a; Perinelli et al., 2011), creating a veined mantle below ancient magmatic provinces. Alternatively, this veined mantle has been interpreted as representing a lithospheric 
refertilization stage resulting from olivine-melt consuming and clinopyroxene-orthopyroxene forming reactions (e.g., Bodinier et al., 2008).

The terminology in use (eclogite versus garnet pyroxenite) is mainly governed by the origin of these rocks. In their review on eclogites and garnet pyroxenites, Gonzaga et al. (2010a) related garnet pyroxenites to high-pressure mantle fractionation processes, and eclogites to recycling of crustal protoliths. Historically, eclogites have been defined as rocks containing pyropegarnet and omphacitic-clinopyroxenes (Haüy, 1822). Moreover, eclogites differ from garnet pyroxenites in that they are more common in cratonic xenolith suites and have a higher jadeite component in clinopyroxenes (Pearson et al., 2005). Despite these differences, multidisciplinary studies are still necessary to decipher the origin of a given sample, and giving an a priori name is therefore hazardous. Hereafter, we will use the petrological term garnet pyroxenite (garnet when more than $10 \%$ garnet is present, and pyroxenite when olivine / [olivine+pyroxenes] < 40\%, following the Streckeisen classification; Streckeisen, 1976).

The mineral assemblages developed in pyroxenites in response to changes in pressure and temperature conditions are of great help in reconstructing the evolutionary stages they underwent in the appropriate geodynamic setting (e.g., Montanini et al., 2006), whereas their chemical and isotopic compositions can be used to decipher their origin and evaluate their potential implication in magma genesis. The absence of modal olivine in mantle pyroxenites is associated with the presence of garnet under spinel lherzolite stability conditions (Kornprobst, 1969); this leads to the existence of two subfacies, namely the Seiland at lower and the Ariegite at higher pressure conditions (O'Hara, 1967). In these two subfacies, the Albearing phases consist of plagioclase and/or spinel, and spinel and/or garnet, respectively. These two subfacies subdivide the spinel lherzolite domain and allow us to determine more precisely the pressure-temperature-time (P-T-t) evolution of the lithosphere than with peridotitic samples. 
99 We present here a petrological and geochemical study of 16 mantle garnet pyroxenite

100 xenoliths (from Morocco, Jordan, Cameroon and France) that represent the rare material 101 available for petro-geochemical studies. The aims of this study are: (i) to evaluate the

102 similarities and/or differences between pyroxenite samples from the different regions; (ii) to

103 constrain the origin of the studied pyroxenites; (iii) to constrain the P-T-t evolution of the

104 studied pyroxenites within the mantle; (iv) to evaluate the relations between the determined P-

105 T-t paths and the geodynamic history of the regional lithosphere; and (v) to discuss the

106 influence of these mantle heterogeneities on the subsequent evolution of the lithosphere.

107

108 2. Regional settings and sampling localities

109 In order to compare the geodynamic evolution and chemical and isotopic composition of

110 pyroxenites, we studied samples from four localities, each with different geodynamic

111 histories: the French Massif Central (Europe), Morocco and Cameroon (Africa) and Jordan

112 (on the Arabian plate; Fig. 1).

113 French Massif Central (FMC): The Massif Central (Fig. 1a) represents one of the biggest parts

114 of the Variscan belt of Western Europe. Alkaline volcanism developed throughout Cenozoic

115 times, with the last manifestation occurring in the Chaîne des Puys 6,900 \pm 110 yr. cal. as the

116 lake Pavin maar (Juvigné et al., 1996). The origin of this volcanism is still debated, and is

117 either attributed to the presence of a thermal anomaly related to a mantle plume (e.g., Granet

118 et al., 1995) or to asthenospheric upwelling related to the nearby Alpine orogeny (Merle and

119 Michon, 2001).

120 Mantle xenoliths are present in several locations of the FMC. Two distinct domains, probably

121 inherited from Hercynian times, are recognized $\mathrm{N}$ and $\mathrm{S}$ of an E-W line located $\sim 45^{\circ} 30^{\prime} \mathrm{N}$

122 (Lenoir et al., 2000). Both domains have been variously depleted through melting 360 Ma

123 ago, and have been enriched by metasomatic fluids (carbonatitic to the North, and rather 
124 related to silicate-melts to the South; Wittig et al., 2007) likely related to the Cenozoic plume 125 (Zangana et al., 1997; Wittig et al., 2007).

126 Three of the studied samples come from the Devès volcanic field (S domain; LN-78 and LP-

12727 from Le Marais de Limagne, and SD-53 from Saint-Didier d'Allier), a basaltic plateau 128 emplaced between 2.7 and 0.6 Ma (Nehlig et al., 2001). Teleseismic tomography studies 129 indicate that the thermal anomaly in the mantle between 100 and $140 \mathrm{~km}$ below the Devès 130 area is the largest of the FMC (Sobolev et al., 1996). One sample comes from Le Pouget, near 131 Montpellier; this locality does not belong to the FMC but, instead, to the 'pyreneo-corso132 sarde' Alpine belt. As the basement of this orogenic segment is also made of old Hercynian 133 lithosphere, the Le Pouget sample will be described together with the FMC samples. This last 134 sample has been briefly studied in previous works (Babkine et al., 1968; Fabriès et al., 1987).

135 Cameroon (Fig. 1b): The oldest Cameroon terrains were structured during Eburnean times 136 some 2.1 Ga ago and were reworked during the Panafrican orogeny (Castaing et al., 1994). 137 Many granite bodies were emplaced around 520 Ma (Lassere et al., 1981).

138 Pyroxenites were sampled in the Youkou maar, in the Adamaoua volcanic plateau (Temdjim, 139 2006). This maar belongs to the Cameroon Volcanic Line (CVL; part of a still-active fault belt 140 in West Africa), which is characterized by important Tertiary and Quaternary alkaline 141 magmatism extending off-continent to several oceanic islands. Volcanism in this area started 142 around $60 \mathrm{Ma}$ ago (Cantagrel et al., 1978) and is still active today. Mantle xenoliths (spinel 143 lherzolites being the most common) are present in volcanic rocks from both oceanic and 144 continental parts of the CVL. Several studies have emphasized a partial melting event 145 probably related to late Proterozoic crust formation (Lee et al., 1996). In many places, the 146 mantle rocks show evidence of interaction with enriched partial melts, probably related to the 147 Mesozoic breakup of Pangaea and the emplacement of the St. Helena mantle plume (Lee et 148 al., 1996; Caldeira and Munha, 2002; Temdjim et al., 2004). 
149 Morocco (Fig. 1c): The middle Atlas area of Morocco is part of the Atlas Mountain range of

150 North Africa and was mainly structured during the Panafrican orogeny, lasting roughly from

151700 to $530 \mathrm{Ma}$ (Gasquet et al., 2005). The orogenic period was followed by the formation of

152 large Paleozoic sedimentary basins that were strongly folded during late Carboniferous-

153 Permian compression (Pique and Michard, 1989). Cenozoic volcanism started before 35 Ma;

154 the last eruptions are probably not older than $0.5 \mathrm{Ma}$ (El Azzouzi et al., 2010) and are

155 tentatively linked to a hot line spreading from the Siroua to Oujda (e.g., El Azzouzi et al., 156 2010).

157 Mantle xenoliths are present in volcanic rocks from the middle Atlas, and show a wide range 158 of lithological and chemical heterogeneity. As in Cameroon, an older melting event is 159 recorded by the chemistry of clinopyroxene (Raffone et al., 2009; Wittig et al., 2010). In most

160 samples, this event has been overprinted by a widespread modal metasomatism (Pezzali et al.,

161 2015). This metasomatic episode is probably very young (less than $200 \mathrm{Ma}$ ) and involves the 162 percolation of alkaline melts with HIMU affinity as well as carbonatitic fluids (Raffone et al., 163 2009; Natali et al., 2013; Pezzali et al., 2015).

164 The Morocco samples come from the Bou-Ibalratene basaltic maar belonging to a volcanic 165 group of nearly 100 monogenic edifices oriented about N170 $\mathrm{E}$, and located South of Azrou 166 in the middle Atlas.

167 Jordan (Fig. 1d): Jordan is located in the northern part of the Arabian-Nubian shield and was 168 affected by important metamorphism and magmatism during the Panafrican orogeny from 640 169 to $540 \mathrm{Ma}$ ago (Stein and Goldstein, 1996). Large alkaline volcanic fields named 'Harrats' are 170 present all along the Arabian plate from Yemen in the South to Jordan and Syria in the North. 171 They are related to the Red Sea and Jordan rifts and were emplaced during Tertiary and 172 Quaternary times (Bertrand et al., 2003). 
173 The Jordan samples come from three different maars belonging to the large, NW-SE trending,

174 Harrat Ash Shaam that extends from SW Syria to the Northern part of Saudi Arabia. Studies

175 concerning Harrat Ash Shaam mantle xenoliths have shown that the mantle in this region was

176 affected by partial melting and refertilization events between 870 and $620 \mathrm{Ma}$ ago. These

177 processes are related to the formation of juvenile crust in a continental arc system (Krienitz

178 and Haase, 2011).

179

180 3. Analytical techniques

181 This study is based on major and trace element and isotope analyses of whole rocks and

182 mineral separates (separated under binocular microscope for their purity after crushing,

183 sieving and washing). In-situ chemical analyses have been made on polished thin sections (30,

184100 or $150 \mu \mathrm{m}$ thick). Details on analytical techniques and settings are given in

185 supplementary material.

186

187

\section{Petrology}

188 4.1. Petrography

189 The sample labels, rock types and modes of the studied samples, and the abbreviations used

190 for minerals are presented in Table 1.

191 Pyroxenites from the FMC have recrystallized granoblastic textures with average grain size of

$1921 \mathrm{~mm}$ for the samples from the Devès volcanic province (LN-78, LP-27 and SD-53); grain

193 size is smaller in the sample from Le Pouget (pyroxenes $\sim 0.25 \mathrm{~mm}$, Spl and Grt $\sim 0.75 \mathrm{~mm}$ ).

194 The prevailing mineral assemblage in all the samples is $\mathrm{Cpx}+\mathrm{Grt}+\mathrm{Opx}+\mathrm{Spl} \pm \mathrm{Am}$. Grt is often

195 located around green Spl and contains green Spl, Pl, Opx and Cpx inclusions that are 196 surrounded by radial fractures (Fig. 2a-b). Those inclusions are remnants of a former

197 paragenesis. In LN-78 larger Cpx grains (>2 mm) display Opx exsolutions (Fig. 2c). This 
sample is composite with an Am-free part and an Am-rich zone. In the three Devès samples,

199 small grains $(50-100 \mu \mathrm{m})$ of Opx, Pl and brownish Spl are locally observed at the contact between Grt and Cpx (Fig. 2d). In all samples, Grt is surrounded by a thin (5 to $40 \mu \mathrm{m}$; Fig.

2b, d) brownish kelyphite rim made of Opx-Pl-Spl (proportions 64:23:13\%, respectively, estimated using mineral compositions and the method of France and Nicollet, 2010).

Samples TAK-3 and TAK-4 from Morocco have a granular texture with an average grain size of $3 \mathrm{~mm}$ and show a penetrative foliation. The paragenesis is $\mathrm{Grt}+\mathrm{Opx}+\mathrm{Cpx}+\mathrm{Spl}$ for TAK-3 and Grt+Cpx+Spl+Spr+Opx for TAK-4. In TAK-3, Grt occurs around the Spl demonstrating an earlier crystallization of Spl, whereas in TAK-4, the Grt-Spl association is observed only locally (Fig. 2e-f). In TAK-3 large Cpx grains (6 mm) contain Grt and Opx exsolutions, and some very thin $(1-2 \mu \mathrm{m}) \mathrm{Spl}$ exsolutions are observed in other Cpx. In TAK-4, Spr is present as inclusions in Spl or Cpx, surrounding the Spl at the Grt contact (Fig. 2e-f), or as thin exsolutions in Cpx. In this same sample a peculiar inclusion is observed in a Cpx grain, containing a Spl+Spr+Pl+Opx assemblage (Fig. 2g). Both samples suffered extended Grt kelyphitization $(\sim 0.4 \mathrm{~mm}$ large in average).

Petrographically, the Cameroon samples can be divided in two groups. The first group (YK01, YK-05 and YK-16) represents initial Cpx megacrysts $(0.5-3 \mathrm{~cm})$ that exsolve Grt grains up to $500 \mu \mathrm{m}$ wide (Fig. 2h-j). In YK-01 Cpx encloses Spl grains that are surrounded by abundant Grt (Fig. 2h). YK-05 megacrysts record a deformation stage and exsolve Opx (Fig. 2i-j). The second group (YK-03, YK-12, YK-13) is characterized by a polycrystalline $\mathrm{Cpx}+\mathrm{Opx}+\mathrm{Grt}+\mathrm{Spl}$ assemblage (average grain size $3 \mathrm{~mm}$ ). In these samples, Grt is either exsolved from Cpx, or localized around Cpx grains and concentrated at the Spl rim. In YK-13, Opx is also localized around Cpx grains and is probably exsolved. In this sample, some apatite is observed, locally included in Grt or Opx. Thin Am exsolutions ( $20 \mu \mathrm{m}$ wide) are also observed in some Cpx grains. In Cpx from all Cameroon samples, very thin $(1-2 \mu \mathrm{m}$ 
223 wide) Spl exsolutions are present; in samples YK-13 and YK-16, these can reach tens of $\mu \mathrm{m}$

224 and are locally surrounded by Grt exsolutions. Am is present in all the samples except YK-01.

225 A thin $(\leq 20 \mu \mathrm{m})$ kelyphitization zone is present around Grt, and a melting zone $(<15 \mu \mathrm{m})$ is

226 often observed at the contact between kelyphite and surrounding minerals. Later surface 227 processes are documented by some carbonate veins that crosscut Grt kelyphite and melting 228 zones.

229 The Jordan samples include Spl Grt pyroxenites (JO-7b and JO-7h) and Grt free 230 orthopyroxenites (JO-10e and JO-12h); JO-12h is an Am-bearing olivine orthopyroxenite. 231 The average grain size in all samples is $1 \mathrm{~mm}$ (Fig. 2k). In JO-7b and JO-7h, Grt $(\sim 50 \mu \mathrm{m})$ is 232 exsolved from pyroxene, around which it concentrates; some Grt also appears around green 233 (in JO-7b, Fig. 2k) or brown (in JO-7h) Spl. In JO-7h some very thin ( 2 $\mu \mathrm{m}$ ) Spl exsolutions 234 are observed in Cpx. In JO-10e orthopyroxenite, rutile is observed along two exsolution 235 directions in Opx (Fig. 21); moreover, this sample is diffusely permeated by dikelets and 236 pockets of carbonate. In JO-7h, Opx is fractured and oxidized at its rim. In both JO-7b and 237 JO-7h, Grt is kelyphitized $(\sim 40 \mu \mathrm{m}$ wide $)$ at the margins.

\subsection{Major element mineral chemistry}

240 Mineral compositions are very homogeneous in each studied sample, allowing us to use 241 average compositions to compare the different samples (Table 2). Cpx and Opx are diopside 242 and enstatite, respectively. Their compositions are broadly similar in the samples from the 243 different provenances (Fig. 3a). In Cpx, wollastonite content is higher than 43\%, ferrosilite 244 content lower that $10 \%$, and jadeite content varies from 4.7 to $12.5 \%$, whereas in Opx 245 wollastonite content is lower than $2 \%$, ferrosilite content varies between 9 and $18 \%$, and 246 jadeite content is below $1 \%$. TAK-4 $\mathrm{Cpx}$ are not stoichiometric; they are silica $247(\mathrm{Si} /(\mathrm{Ca}+\mathrm{Na}+\mathrm{Mg}+\mathrm{Fe})=1.04)$ and $\mathrm{Ca}\left(\mathrm{X}_{\mathrm{W}_{0}}=0.51\right)$ enriched. Grt are pyrope (Fig. 3b), with 
compositions between 62 and 73\% for the pyrope component $(\mathrm{Mg})$ and between 11 and 24\%

249 for the almandine component $(\mathrm{Fe})$ at a nearly constant grossular (Ca) content $(\sim 13 \%)$. Spl show a wide range of compositions. The $\mathrm{Cr}_{2} \mathrm{O}_{3}$ vs. $\mathrm{Al}_{2} \mathrm{O}_{3}$ anti-correlation $\left(\mathrm{R}^{2}=0.96\right)$ is related to the $\mathrm{Al}-\mathrm{Cr}$ substitution in $\mathrm{Spl}$ and shows a variation from 0 to $30 \%$ of the chromite

component. For all the studied samples, the ratio $M g$-component/Fe ${ }^{2+}$-component (spinel s.s./hercynite) is around 2, and \#Cr varies from 1 to $12 \%$ in all samples except JO-12h, for which the value is $30.5 \%$ (with $\# \mathrm{Cr}=\mathrm{Cr} /(\mathrm{Cr}+\mathrm{Al}$ ) in molar proportions). For the samples displaying two Spl generations (LN-78, LP-27 and SD-53), the brown ones (second generation) are poorer in chromite component than the primary green ones. Pl compositions are variable, ranging from andesine in FMC samples (with anorthite content varying from 35 to $47 \mathrm{~mol} \%$ ), to bytownite in TAK-4 (Morocco; $\mathrm{An}_{84}$ ). Analyzed amphiboles are magnesiohastingsites in LN-78, YK-05 and YK-13, pargasites in YK-03 and ferro-edenite in JO-12h. Olivine is $\mathrm{Fo}_{89}$ in JO-12h.

\section{Mineral trace element compositions}

Trace element compositions of minerals have been obtained for $\mathrm{Cpx}$ and Grt in all samples, and for Am, Pl, and Opx when these minerals were large enough (Table 3). Cpx trace element composition is variable in the different samples, and sometimes within a single sample. In FMC samples (Fig. 4a), the Cpx show variable light-rare earth elements (LREE) contents, ranging from strongly depleted (in Le Pouget sample) to slightly enriched compared to the medium-REE (MREE). They are also depleted in heavy-REE (HREE), reflecting their chemical equilibrium with Grt (see section 8.1.2 "Cpx/Opx and Cpx/Grt partition coefficients"). In sample LN78, some Cpx located close to Am grains are highly enriched in

LREE, less HREE depleted than other Cpx, and have REE content similar to associated Am grains. In the two Morocco samples (Fig. 4a), the Cpx have REE normalized contents that 
273 decrease from the LREE to the HREE region. In TAK-4 the decrease from the LREE to the

274 HREE is more pronounced than in TAK-3 and slight positive Eu and Sr anomalies are present 275 (Fig. 4b). Similar to their analogues from FMC, Cpx in the Cameroon samples are all HREE 276 depleted (Fig. 4c), in agreement with the presence of Grt. Their LREE composition is variable 277 and ranges from 0.6 to more than 10 times the chondrite value. Grt-bearing samples from 278 Jordan show two types of Cpx compositions (Fig. 4c); Cpx grains in contact with Grt are 279 strongly depleted in HREE relative to MREE, whereas those far from Grt are only slightly 280 depleted. Their LREE content is also variable, from largely depleted in JO-7b to slightly 281 enriched in JO-7h. In Grt-free samples, Cpx possess higher REE abundances and are LREE 282 enriched. In all these samples, Cpx have very low $\mathrm{Nb}$, Ta and often $\mathrm{Zr}$ and $\mathrm{Hf}$ contents (Fig. 283 4b, d). All the analyzed Grt grains show typical REE patterns, highly enriched in HREE (up to 284 100x chondrite in TAK-3 from Morocco) in comparison to largely depleted LREE contents 285 (Fig. 4e). Some Grt display relatively flat patterns from MREE to HREE, reflecting the low HREE contents of the whole rock. Grt is strongly enriched in U (Fig. 4f). Pl in FMC samples is LREE enriched and shows strong Eu, $\mathrm{Sr}$ and Ba positive anomalies (Table 3).

\section{Whole rock major and trace element compositions}

290 Whole rock major element compositions are summarized in Table 4 and Figure 5. Mg\# 291 (where $\mathrm{Mg} \#=\mathrm{Mg} /(\mathrm{Mg}+\mathrm{Fe}$ ) in molar proportions) varies from 79.8 in $\mathrm{SD}-54$ (FMC) to 89.3 292 in JO-7h (Jordan; Table 4). $\mathrm{SiO}_{2}$ content ranges from 42.6 to $54.7 \mathrm{wt} \%$; the lowest values are 293 found in the two samples from Morocco which are thus classified as ultramafic rocks while all 294 other samples are mafic rocks (Le Bas and Streckeisen, 1991). MgO content varies from 15.5 $295 \mathrm{wt} \%$ in LP-27 (FMC) to $33.1 \mathrm{wt} \%$ in JO-12h (Jordan). $\mathrm{Al}_{2} \mathrm{O}_{3}$ content ranges from $3.2 \mathrm{wt} \%$ in 296 JO-10e (Jordan) to $22.5 \mathrm{wt} \%$ in TAK-4 (Morocco). CaO content varies from $1.7 \mathrm{wt} \%$ in JO297 12h (Jordan) to $16.4 \mathrm{wt} \%$ in Le Pouget sample (FMC). $\mathrm{FeO}_{\mathrm{t}}$ (all iron expressed as $\mathrm{FeO}$ ) 
content varies from $4.6 \mathrm{wt} \%$ in $\mathrm{JO}-7 \mathrm{~h}$ (Jordan) to $8.1 \mathrm{wt} \%$ in $\mathrm{JO}-10 \mathrm{e}$ (Jordan). $\mathrm{Na}_{2} \mathrm{O}$ content ranges from $0.04 \mathrm{wt} \%$ in JO-12h (Jordan) to $1.41 \mathrm{wt} \%$ in YK-13 (Cameroon). In all the oxideoxide composition plots, whole rock compositions plot between the main bearing minerals, namely Cpx, Opx, Spl, and Grt. Some samples, especially those from Morocco, are furthermore slightly shifted toward the $\mathrm{Spl}$ and/or Spr composition. $\mathrm{MgO}$ is correlated with $\mathrm{SiO}_{2}$, and anticorrelated with $\mathrm{CaO}$ and $\mathrm{Al}_{2} \mathrm{O}_{3}$. The average composition of primitive MORB and alkaline melts are added in Figure 5, and are considered as possible proxies of a prospective trapped melt in mantle domains.

Whole rock trace element concentrations are summarized in Table 4 and Figure 6 . Whole rock REE content for FMC pyroxenites show typical spoon-shaped patterns with high HREE content, depletion in MREE and enrichment in LREE (Fig. 6a). The two different parts of LN78 have parallel REE patterns, the Am-rich part being more LREE enriched; Le Pouget sample possesses similar MREE and HREE composition, but is largely depleted in LREE, with La lower than 0.1x chondrite, in agreement with its strongly LREE depleted Cpx (Fig. 4a). The two samples from Morocco have contrasting REE compositions; TAK-3 pyroxenite shows a pattern similar to the FMC pyroxenites, whereas the Spr-bearing TAK-4 sample has a very low HREE content $(<3 x$ chondrite) coupled with a marked LREE enrichment $(\mathrm{La}>35 \mathrm{x}$ chondrite), and a small positive Eu anomaly associated with a positive $\mathrm{Sr}$ anomaly. Similar to the FMC samples, two types of REE patterns are displayed by the Cameroon pyroxenites (Fig. 6c); they all have low HREE content, and most of the samples are LREE depleted. Only two samples (YK-13 and YK-16) show LREE enrichment. The pyroxenites from Jordan also have contrasted REE patterns (Fig. 6e). Three samples are LREE enriched, with $(\mathrm{La} / \mathrm{Yb})_{\mathrm{n}}$ values ranging from 2.5 to 7 and quite variable HREE compositions, while sample $\mathrm{JO}-7 \mathrm{~b}$ is LREE depleted. 
322 In trace element spider diagrams (Fig. 6b, d, f), all samples present large negative $\mathrm{Rb}$ and $\mathrm{Nb}$ 323 anomalies, associated with negative $\mathrm{Zr}$ anomalies (except for TAK-3 that displays a slight 324 positive anomaly). Most of the samples also display a positive $\mathrm{Sr}$ anomaly; only JO-10e 325 (Jordan) displays a negative Sr anomaly.

\section{Isotopic data}

328 Sr-Nd isotope data have been obtained on separated Cpx from four samples from Jordan, three 329 from Cameroon, and two from Morocco (Table 5; not enough material was available for other 330 samples). ${ }^{87} \mathrm{Sr} /{ }^{86} \mathrm{Sr}$ values are homogeneous and range from 0.702661 to 0.703375 (Fig. 7 ); in 331 contrast, ${ }^{143} \mathrm{Nd} /{ }^{144} \mathrm{Nd}$ values are more variable and range between 0.512774 and 0.513433 . 332 Both the lowest and highest values are observed in Jordan samples. All the samples, except $333 \mathrm{JO}-7 \mathrm{~b}$ and TAK-3, plot below the mantle array; most values are close to the HIMU component (Zindler et Hart, 1986).

33550 analyses of oxygen isotopic ratios have been obtained on Cpx, Opx, Grt and Spl separates 336 (Table 5). Most of the values fall within the mantle range for peridotites (Ionov et al., 1994; 337 Mattey et al., 1994a; Chazot et al., 1997; Zhang et al., 2000), with $\delta^{18}$ O ranging from 4.82 to $338 \quad 5.72 \%$ for $\mathrm{Cpx}$, from 4.94 to $6.12 \%$ for Opx, from 5.15 to $5.97 \%$ for Grt, and from 4.33 to $3394.97 \%$ for Spl (Fig. 8). Fractionation between Grt and Cpx is positive and close to 0.3\%o with 340 the exception of three samples from Cameroon having slightly negative fractionation values 341 (Fig. S1a). Fractionation between Opx and Cpx is also positive (except for two samples, Fig. $342 \mathrm{~S} 1 \mathrm{~b}$ ), and in the range of values observed in mantle lherzolites from Yemen (Chazot et al., 343 1997).

\section{Discussion}


346 The various petrographical and geochemical data presented are discussed hereafter to 347 determine the last equilibration stage conditions $\left(\mathrm{T}, \mathrm{fO}_{2}\right.$, section 8.1$)$ of the studied Grt 348 pyroxenites, and to track their origin (recycled or not?, section 8.2) and the metasomatic 349 reactions they subsequently suffered (section 8.3). Pyroxenite pressure-temperature variations 350 through subsolidus evolution are reconstructed for each sample (section 8.4), and the apparent 351 inter- and intra-region variability (petrographical and geochemical) are discussed in section 352 8.5. Finally we present our hypothesis in a geodynamic framework to discuss implications in terms of mantle refertilization (section 8.6).

\subsection{Last equilibration stage conditions}

\subsubsection{Thermometry and oxybarometry}

357 Equilibrium temperature $(\mathrm{T})$ estimates are presented in Table 1. Opx-Cpx equilibrium $\mathrm{T}$ of 358 Grt-bearing peridotites and pyroxenites are best estimated using the Taylor (1998) 359 geothermometer (Wu and Zhao, 2012), and are as follows: $730^{\circ} \mathrm{C}$ and $930-1080^{\circ} \mathrm{C}$ (Le Pouget 360 and other FMC samples, respectively), $910^{\circ} \mathrm{C}$ (TAK-3, Morocco), $780-810^{\circ} \mathrm{C}$ (Jordan), and $361900-980^{\circ} \mathrm{C}$ (Cameroon). Equilibrium $\mathrm{T}$ cannot be estimated for TAK-4 since it contains 362 aluminous diopside. For comparison, Opx-Grt equilibrium T, calculated using the Nimis and 363 Grütter (2010) geothermometer, are as follows: $715-1020^{\circ} \mathrm{C}$ (FMC), $890^{\circ} \mathrm{C}$ (TAK-3, 364 Morocco), $720-760^{\circ} \mathrm{C}$ (Jordan), and $870-980^{\circ} \mathrm{C}$ (Cameroon). In general, equilibrium $\mathrm{T}$ 365 calculated with both geothermometers are consistent. Because 2+ cations diffuse faster than $3663+$ cations, $\mathrm{T}$ calculated using major element based thermometers are likely to be indicative of 367 late stage equilibration $\mathrm{T}$, whereas REE-in-two-pyroxene thermometers are expected to be 368 indicative of sub-magmatic T (e.g., Liang et al., 2013). Valid results have been obtained using 369 the Liang et al. (2013) model for two samples from the present study: LN-78: $1376 \pm 126{ }^{\circ} \mathrm{C}$, 
370

371 magmatic stage.

372 Redox conditions of mantle domains are usually estimated using oxybarometers that 373 from 0.56 to 0.83 for an average value of 0.73 (Fig. 9).

and LP-27: $1194 \pm 69{ }^{\circ} \mathrm{C}$; those equilibrium $\mathrm{T}$ are consistent with the record of an early necessitate olivine bearing-rocks (e.g., Goncharov and Ionov, 2012), and are thus not appropriate for the olivine-free pyroxenites studied here. $\mathrm{Fe}^{3+}$ concentrations in $\mathrm{Cpx}$, Opx, and Grt have been estimated using stoichiometric criteria following the classical approach of Droop (1987); corresponding $\mathrm{Fe}^{3+} / \Sigma \mathrm{Fe}$ values are reported in Table $\mathrm{S} 1$ and Fig. 9. Although such calculation results should be taken with caution, good correlations exist between $\left(\mathrm{Fe}^{3+} / \Sigma \mathrm{Fe}\right)_{\mathrm{Opx}}$ and $\left(\mathrm{Fe}^{3+} / \Sigma \mathrm{Fe}\right)_{\mathrm{Cpx}}\left(\mathrm{R}^{2}=0.69\right)$, between $\left(\mathrm{Fe}^{3+} / \Sigma \mathrm{Fe}\right)_{\mathrm{Grt}}$ and $\left(\mathrm{Fe}^{3+} / \Sigma \mathrm{Fe}\right)_{\mathrm{Opx}}$ $\left(\mathrm{R}^{2}=0.85\right)$, and between $\left(\mathrm{Fe}^{3+} / \Sigma \mathrm{Fe}\right)_{\mathrm{Grt}}$ and $\left(\mathrm{Fe}^{3+} / \Sigma \mathrm{Fe}\right)_{\mathrm{Cpx}}\left(\mathrm{R}^{2}=0.71 ;\right.$ Fig. 9). Those good correlations strongly support the validity of the stoichiometric calculations for the present study: $\left(\mathrm{Fe}^{3+} / \Sigma \mathrm{Fe}\right)_{\mathrm{Cpx}}$ ranges from 0 to $0.6,\left(\mathrm{Fe}^{3+} / \Sigma \mathrm{Fe}\right)_{\mathrm{Opx}}$ from 0 to 0.22 , and $\left(\mathrm{Fe}^{3+} / \Sigma \mathrm{Fe}\right)_{\mathrm{Grt}}$ from 0 to 0.21 . $\left(\mathrm{Fe}^{3+} / \Sigma \mathrm{Fe}\right)_{\text {Melt }}$ was calculated using $\left(\mathrm{Fe}^{3+} / \Sigma \mathrm{Fe}\right)_{\mathrm{Cpx}}$ values and the approach formulated in France et al. (2010). Rough estimates for $\triangle$ FMQ (Fayalite-Magnetite-Quartz oxygen fugacity buffer) were obtained using the correlation between $\Delta \mathrm{FMQ}$ and $\left(\mathrm{Fe}^{3+} / \Sigma \mathrm{Fe}\right)_{\mathrm{Grt}}$ presented by Goncharov and Ionov (2012). $\left(\mathrm{Fe}^{3+} / \Sigma \mathrm{Fe}\right)_{\text {Melt }}$ is plotted against $\Delta \mathrm{FMQ}$ in Fig. 9.

More generally, the FMC samples appear to be the most reduced pyroxenites with $\left(\mathrm{Fe}^{3+} / \Sigma \mathrm{Fe}\right)_{\text {Melt }}$ ranging from 0.4 to 0.6 ; Jordan pyroxenites are slightly less reduced with an average $\left(\mathrm{Fe}^{3+} / \Sigma \mathrm{Fe}\right)_{\text {Melt }}$ of 0.6 ; the average $\left(\mathrm{Fe}^{3+} / \Sigma \mathrm{Fe}\right)_{\text {Melt }}$ for Morocco samples is 0.66 ; and Cameroon samples are the most oxidized samples studied herein with $\left(\mathrm{Fe}^{3+} / \Sigma \mathrm{Fe}\right)_{\text {Melt }}$ ranging

\subsubsection{Cpx/Opx and Cpx/Grt partition coefficients}

The major element compositional homogeneity of all the minerals among the studied samples, and the presence in most of the samples of well-developed exsolution lamellae indicate that 
395 (at least partial) intra-sample equilibrium was achieved; this is supported by the typical mantle

396 T calculated from the chemical composition of Cpx, Opx and Grt (Table 1). Oxygen isotope 397 data also show that no large disequilibrium exists between minerals in the studied pyroxenites.

398 This chemical equilibrium among minerals was also tested by trace element partition 399 coefficient calculations between Cpx and Opx, and between Cpx and Grt in the different 400 samples (Fig. 10). The calculated $\mathbf{K}_{\mathbf{D}(\mathbf{C p x}-\mathbf{G r t})}$ values are in the range of values published by 401 Viljoen et al. (2005) for group II eclogites from South Africa, interpreted as crystallization 402 products of small-volume melts in the lithospheric mantle. Our values are also very similar to those obtained in a Cpx megacryst aggregate crystallized from a MORB type magma in the lithospheric mantle of China (Huang et al., 2007), and to $\mathbf{K}_{\mathbf{D} \text { (Cpx-Grt) }}$ determined experimentally at pressures varying from 2 to 3 GPa (Johnson, 1994). K $\mathbf{K}_{\mathbf{D}(\mathbf{C p x}-\mathbf{G r t})}$ are dependent on the major element phase compositions (e.g., Harte and Kirkley, 1997);

407 calculations accounting for mineral compositions align closely with $\mathbf{K}_{\mathbf{D}(\mathbf{C p x} \text {-Grt) }}$ values 408 obtained in the present study (Fig. 10). These results support that Cpx and Grt have attained 409 chemical equilibrium at mantle conditions in all the studied samples before their fast transport 410 to the surface. $\mathbf{K}_{\mathbf{D} \text { (Cpx-Opx) }}$ values are compared to results obtained by Raffone et al. (2009) on 411 lherzolites and harzburgites from Morocco (Fig. 10). Although a strong variability is observed 412 in our data (due to large errors on the trace element concentrations of Opx that are strongly 413 depleted in trace elements), $\mathbf{K}_{\mathbf{D}(\mathbf{C p x}-\mathbf{O p x})}$ are in the range of mantle values determined by 414 Raffone et al. (2009).

\subsection{Pyroxenite origin as mantle cumulates}

417 It is still a matter of debate whether pyroxenite xenoliths brought to the surface by volcanic 418 processes represent metamorphically transformed crustal rocks (of either continental or 419 oceanic origin) or are the final products of melt circulation, crystallization and evolution in the 
mantle. Here we use highly detailed petrological observations and major and trace element compositions, coupled with stable and radiogenic isotopic compositions to decipher their origin.

\subsubsection{Whole rock compositions as a proxy of initial cumulative assemblages}

Whole rock major element compositions define relatively good correlations for $\mathrm{SiO}_{2}$, $\mathrm{CaO}$ and $\mathrm{Al}_{2} \mathrm{O}_{3}$ versus $\mathrm{MgO}$ content (Fig. 5), and $\mathrm{Al}_{2} \mathrm{O}_{3}$ and $\mathrm{SiO}_{2}$ are also well correlated. The pyroxenites studied here show an increase in $\mathrm{SiO}_{2}$ content correlated to an increase in $\mathrm{MgO}$ (Fig. 11), which is in contrast to classic liquid lines of descent that highlight melt differentiation processes (e.g., for MORB, calc-alkaline, or alkaline rocks) characterized by a decrease in $\mathrm{MgO}$ when $\mathrm{SiO}_{2}$ increases. High concentrations of highly compatible elements such as $\mathrm{Ni}$ can be used to identify cumulative rocks, in which their concentration is by definition higher than in the corresponding equilibrium melts. The Ni content of the studied pyroxenites $(\sim 300-900 \mathrm{ppm})$ is much higher than most primitive MORBs $(\sim 300 \mathrm{ppm}$, and decreasing with differentiation; Fig. 11), indicating that they cannot represent liquids, but rather are cumulates (either s.s. cumulates or cumulates resulting from percolative fractional crystallization). At this stage of discussion, their origin as crustal or mantle cumulates cannot be deciphered.

Since the studied pyroxenites represent cumulative rocks, their whole rock composition (major and trace elements) is indicative of the modal proportion of the initial cumulative assemblage; for example, the high $\mathrm{Ni}$ content attests to the presence of Spl among the cumulative minerals. We now present evidence supporting the assemblages that are reported in Table 1. The presence of magmatic Grt in four samples (FMC samples, and TAK-3 from Morocco; Fig. 6) is confirmed by the whole rock enrichment in HREE relative to MREE. The major element composition and $\mathrm{Ni}$ content of those samples also indicate that Cpx-Opx-Spl 
445 were part of the initial cumulative assemblage (red dotted samples in Fig. 5). Among the 446 studied pyroxenites, 3 samples from Cameroon (YK-01, YK-03, YK-12) display small but 447 significant positive Eu anomalies (Fig. 6), classically indicating magmatic Pl. However, 448 similar anomalies have been reported in spinel-bearing peridotitic Cameroon mantle, and 449 attributed to regional metasomatism (e.g., Temdjim et al., 2004). This signature being 450 regional, and in the absence of other evidence, we follow their interpretation and infer that Pl 451 was not part of the initial cumulative assemblage in Cameroon samples. Only TAK-4 from 452 Morocco displays coupled positive Eu and $\mathrm{Sr}$ anomalies (Fig. 6) that have not been reported 453 for peridotitic samples from this area, and should be attributed to the presence of Pl in the 454 initial cumulative assemblage. In this sample, the major element and Ni concentrations point 455 to the additional presence of $\mathrm{Cpx}$ and $\mathrm{Spl}$ in the initial cumulative assemblage (Fig. 5). Major 456 elements and $\mathrm{Ni}$ concentrations of Cameroon samples demonstrate that $\mathrm{Cpx}-\mathrm{Sp}( \pm \mathrm{Opx})$ were 457 part of the initial cumulative assemblage in all samples (Fig. 5), consistent with petrographic observations. Petrographic relations also suggest that apatite was present as a magmatic mineral in YK-13. According to petrography, major elements, and Ni contents, Opx was the 460 main cumulative mineral in JO-10e and JO-12h, together with Ol-Spl-Cpx in JO-12h, and 461 Spl-Cpx in JO-10e; two pyroxenes and Spl were present in the initial cumulative assemblages 462 of JO-7b, and 7h (Fig. 5, Table 1).

463 In addition to the cumulative mineral record, Downes (2007) invoked a trapped melt 464 component to account for the whole rock major element compositions of orogenic pyroxenites 465 interpreted to be mantle cumulates. In order to test this hypothesis, the compositions of 466 relatively primitive mantle melts (represented by primitive MORBs and alkaline basalts) have 467 been added to all graphs of Fig. 5. Only two samples (LP-27 from FMC, and YK-13 from 468 Cameroon) seem to record a slight influence of trapped melt in their whole rock composition, 469 as highlighted by their high $\mathrm{Na}_{2} \mathrm{O}$ contents. This hypothesis is consistent with the LREE 
470

471

472

473

474

475

476

477

478

479

480

481

482

483

484

485

486

487

488

489

490

491

492

493

494

enrichment of those samples; in addition YK-13 is the only sample to contain early magmatic apatite, also consistent with a possible trapped melt component.

The initial cumulative assemblages determined here will be used in section 8.4 to determine the in which mantle domain crystallization occurred. Finally the major and trace element whole rock compositions of the studied cumulative pyroxenites are only representative of the initial cumulative assemblage (nature of the phases and modal composition) and are thus not indicative of the composition of the parental melts that thus cannot be determined.

An alternative hypothesis to the cumulative origin of the studied pyroxenites is that Grtpyroxenites form as refractory residues after partial melting of eclogitic metagabbros (e.g., Montanini et al., 2012). However, residual Grt-pyroxenites are expected to preserve the initial $\mathrm{Eu}$ and $\mathrm{Sr}$ anomalies that are characteristic of eclogites with a recycled origin (Marchesi et al., 2013). In addition, we have identified that the initial cumulative assemblages are, depending on the studied pyroxenites, either Cpx-Opx-Grt-Spl or Cpx-Opx-Spl ( $\pm \mathrm{Pl}, \pm \mathrm{Ol}, \pm \mathrm{Ap}$; Table 1), which is not consistent with residual assemblages derived from either gabbroic protoliths (Montanini et al., 2012; Marchesi et al., 2013) or Pl-free pyroxenites or eclogites (Kogiso et al., 2003; Lambart et al., 2009). Such a model is therefore not valid for the pyroxenites studied here.

TAK-3 and TAK-4 Grt-bearing pyroxenites from Morocco are slightly off the general trends observed for major elements (Fig. 5). These samples are shifted toward Spl and/or Spr compositions in most oxide composition diagrams, suggesting that higher amounts of Spl and/or Spr were present as primary magmatic phases in these samples. The possibility that Spr is a liquidus phase in mafic to intermediate magmas at high pressure conditions (from 1.1 to 3 GPa) has been highlighted by Liu and Presnall (2000). However, these authors pointed out that Spr has rarely been described as a magmatic phase in natural rocks as it mostly occurs as a metamorphic mineral. Textural, petrological and geochemical evidence presented here does 
not clarify an igneous or metamorphic origin of Spr; this will be further discussed in section 8.4 'P-T-t path reconstructions'.

In summary, the studied pyroxenites represent cumulative rocks that initially crystallized Cpx, Opx, and for some samples Grt and Spl (with trace apatite in one sample; Table 1); Pl was part of the initial cumulative assemblage in only one sample (TAK-4). Such cumulative assemblages are not expected in lower crustal (continental \& oceanic) settings where $\mathrm{Pl}$ is usually the dominant phase. Additionally, $\mathrm{Px} \pm \mathrm{Spl} \pm \mathrm{Grt}$ cumulates are expected at shallow mantle depths according to experimental petrology constraints (e.g., Green \& Ringwood, 1967), and are very commonly described among mantle xenoliths (e.g., Kaeser et al., 2009; Perinelli et al., 2011) or in orogenic ultramafic massifs (e.g., Downes, 2007). The likely mantle origin of the studied cumulates can be further tested using isotopic constraints.

\subsubsection{Isotopic constraints support a mantle protolith}

The oxygen isotopic composition of minerals is useful for constraining mantle versus recycled origins of pyroxenites and eclogites (e.g., Downes, 2007; Gonzaga et al., 2010a). Cpx, Grt, Opx, and Spl analyzed in this study have oxygen isotopic values typical of mantle minerals (4.8-6.1\%o, Fig. 8; e.g., Mattey et al., 1994a; Chazot et al., 1997), in contrast to more variable compositions of Cpx and Grt in recycled eclogites (2-10\%o; e.g., Mattey et al., 1994b; Gonzaga et al., 2010a) and bulk oceanic crust (3.7-13.6\%o; e.g., Gregory and Taylor, 1981). Deep crustal portions of oceanic crust (primarily Pl-rich cumulates) may display typical mantle values (Gao et al., 2006), but are distinct due to strong Eu anomalies not observed in the pyroxenites studied herein. Major element compositions of the studied pyroxenites do not overlap the composition of neither volcanic, nor plutonic oceanic crust (Fig. 11), also strongly supporting that studied pyroxenites do not derive from recycled oceanic crust. It should be noted here that similar cumulative rocks have been recognized at Moho depth in the Kohistan 
520

521

522

523

524

overthickened arc crust (35-45 km; Burg, 2011). The studied pyroxenites are therefore most likely mantle cumulates; only TAK-4, which displays mantle like $\delta^{18} \mathrm{O}$ values and magmatic $\mathrm{Pl}$, may represent either a shallow mantle or deep crustal cumulate. Inter-mineral $\delta^{18} \mathrm{O}$ variations are presented in supplementary figure $S 1$; as a whole they are consistent with a mantle origin.

Sr-Nd isotope data obtained on Cpx separates are used to test our previous conclusions. Garrido et al. (2000) showed that $\sim 65 \%$ of the Sr concentration of an ultramafic rock, and $\sim 15 \%$ of the $\mathrm{Nd}$, is hosted in solid, melt, and fluid inclusions, as well as grain boundaries; $\mathrm{Sr}-$ $\mathrm{Nd}$ isotopic data obtained on Cpx separates (the main REE bearing mineral) should thus be preferred to whole rock measurements. As a whole, the studied pyroxenites have $\mathrm{Sr}$ and $\mathrm{Nd}$ isotopic ratios that are slightly above and below, respectively, the average DMM composition (Fig. 7), in contrast to recycled eclogites that display more heterogeneous values than the host mantle (Gonzaga et al., 2010a). Only two samples, TAK-3 and JO-7b (from Morocco and Jordan, respectively), have higher $\mathrm{Nd}$ isotope ratios compared to DMM. The $\mathrm{Nd}$ isotopic signature of JO-7b closely matches that of another garnet pyroxenite from Israel (BS-701 in Stein et al., 1993) and peridotite samples from Saudi Arabia (Henjes-Kunst et al., 1990; Blusztajn et al., 1995), and is probably a time integrated effect of a high $\mathrm{Sm} / \mathrm{Nd}$ ratio ( $\mathrm{Sm} / \mathrm{Nd}$ $=0.566$; e.g., Borghini et al., 2013), which is the highest among all the samples. TAK-3 from Morocco does not have a high $\mathrm{Sm} / \mathrm{Nd}$ ratio, but its isotopic composition is very close to that of lherzolite and websterite samples analyzed in the same area (Raffone et al., 2009). Excluding TAK-3 and JO-7b, the Sr-Nd isotopic compositions of the studied pyroxenites, although heterogeneous, overlap those obtained on mantle rocks from the various areas considered (Fig. 7), as is expected for pyroxenites with origins as segregations from mantle melts (e.g., Downes, 2007; Gonzaga et al., 2010a). 
544 Our findings are in agreement with numerous previous studies identifying mantle pyroxenites

545 as mantle cumulates rather than the products of deep crustal recycling (O'Hara and Yoder, 546 1967; Frey, 1980; Downes, 2007; Griffin \& O’Reilly, 2007; Perinelli et al., 2011). The 547 opposing view that mantle heterogeneities originate mainly from recycling associated with 548 subduction zones (Allègre and Turcotte, 1986) is not applicable to most of the studied 549 samples.

\subsection{Evidence for subsequent metasomatic interactions}

552 Most of the studied pyroxenites show evidence of late melt percolation and cryptic and/or 553 modal metasomatism. Two samples from Cameroon (YK-13 and YK-16) are LREE enriched 554 and sample YK-05, although LREE depleted, shows a slight enrichment in La compared to 555 Ce. These LREE enriched samples also have high concentrations in $\mathrm{Ba}, \mathrm{Sr}, \mathrm{U}$ and $\mathrm{Th}$ and low 556 concentrations in $\mathrm{Zr}$ and Hf. This metasomatic signature has already been observed in spinel 557 lherzolites from the Nyos volcano along the CVL (Temdjim et al., 2004), and is therefore a regional overprint. The Morocco pyroxenites are also enriched in LREE, Ba, U, Th and Sr, although more markedly in TAK-4 than in TAK-3. Raffone et al. (2009) documented similar

560 enrichments in peridotite xenoliths from the same volcanic province and showed that they are 561 related to alkaline melt percolation, probably associated with late Cretaceous or Eocene 562 volcanism. A metasomatic overprint is also present in three of the four studied Jordan 563 samples. Spidergrams highlight the LREE enrichment relative to MREE, and positive Ba, U, 564 and Th anomalies that are similar to metasomatic enrichments previously described in Jordan 565 lithospheric mantle, and possibly related to Pan-African subduction (Shaw et al., 2007). 566 Metasomatism is also evident in the pyroxenites from the FMC. All the whole-rocks, except 567 the southernmost sample (Le Pouget), have spoon-shaped REE patterns with decreasing REE 568 content from Lu to $\mathrm{Nd}$, and are enriched in LREE (La, Ce and Pr), clearly pointing to LREE 
depleted protoliths, further enriched by LREE-rich percolating melts. These samples are also highly enriched in $\mathrm{U}$ and $\mathrm{Th}$, and sometimes depleted in $\mathrm{Nb}, \mathrm{Zr}$ and $\mathrm{Hf}$.

LN-78 is a composite sample with an Am-bearing and an Am-free part. In the Am-bearing part, Cpx is more LREE-enriched, and is in chemical equilibrium with coexisting Am as attested by the $D_{R E E}^{C p x / A m} \approx 1$ (Chazot et al., 1996). In the Am-free part, Cpx has complex REE patterns with HREE decreasing from $\mathrm{Eu}$ to $\mathrm{Lu}$ due to preferential incorporation of these elements in coexisting Grt. Rare earths were initially decreasing from Eu to La (similar to Le Pouget sample), but La and Ce have been selectively enriched during melt percolation and crystallization of Am and Cpx in the Am-bearing part of the sample; similar conclusions have been proposed by Downes et al. (2003). Similar metasomatic overprints with LREE, U, and Th enrichments, and $\mathrm{Zr}$-Hf and $\mathrm{Nb}$-Ta depletions have been observed in peridotite xenoliths from different localities in the FMC (Lenoir et al., 2000, Féménias et al., 2003, Dautria et al., 2010); those overprints are ascribed for most of the elements to Variscan (or late Variscan) -possibly subduction-related -- metasomatism (Lenoir et al., 2000; Féménias et al., 2003). Other authors link this metasomatic event to the arrival of a mantle plume head in the early Cenozoic (Dautria et al., 2010). Some xenoliths originated in the southern part of the FMC do not show any metasomatic overprint (Dautria et al., 2010), in agreement with the lack of enrichment in the Le Pouget sample.

A metasomatic overprint may be hard to distinguish from a trapped melt component present in the initial cumulative assemblage. Na content may be used as it is not expected to be particularly enriched by metasomatic fluid percolation in comparison to other major elements, however it is useful to track a trapped melt component in cumulates (see section 8.2.1, and Fig. 5). Among the studied samples only LP-27, and YK-13 have been shown to record a trapped melt component; all trace element characteristics discussed above for the other samples are likely related to metasomatic enrichments. 
594 As discussed in Pezzali et al. (2015), the samples displaying the weakest metasomatic

595 overprint can be considered as geochemical remnants of the pre-metasomatic lithospheric 596 mantle. Those are Le Pouget sample for FMC lithospheric mantle, Jo-7b for Jordan 597 lithospheric mantle, YK-01, and YK-12 for Cameroon lithospheric mantle.

\subsection{P-T-t path reconstructions and pyroxenite evolution within mantle domains}

600 Various geochemical data presented here have highlighted an origin as mantle fractionated 601 melts for the studied samples. Precise petrological observations and whole rock trace element 602 contents are here used to constrain the $\mathrm{P}$ evolution of these cumulates and to reconstruct the 603 corresponding P-T-t paths. To proceed, the P-T stability fields, the associated facies and

604 subfacies, and the corresponding subsolidus reactions separating lithospheric mantle domains, 605 documented in Fig. 12a, will be considered. Initial cumulative assemblages, and the sequence 606 of subfacies crossed during the P-T-t evolution are recalled in Table 1.

607 FMC pyroxenites display recrystallized textures resulting from various sub-solidus mineral 608 reactions. Grt entered the mineral assemblage as a liquidus phase (section 8.2), consistent with 609 a first crystallization of the FMC pyroxenites in the Ariegite subfacies (Fig. 12b). However 610 the numerous inclusions (green Spl, Cpx, Opx and Pl; Fig. 2a-b) observed in Grt show that the 611 present-day Ariegite-subfacies mineral assemblage $(\mathrm{Cpx}+\mathrm{Grt}+\mathrm{Opx}+\mathrm{Spl} \pm \mathrm{Am})$ does not 612 represent that of the initial cumulate, but rather derivates from metamorphic reactions. This 613 mineral assemblage preserved as inclusions in Grt thus testifies for an early Seiland 614 pyroxenite facies assemblage. Some large Cpx grains (up to $2 \mathrm{~mm}$ ) containing Opx 615 exsolutions (Fig. 2c) have escaped the general recrystallization process and are still 616 reminiscent of an early cooling. A demixing $\mathrm{T}$ of $\sim 1275^{\circ} \mathrm{C}$ is estimated for sample $\mathrm{LN}-78$ 617 using image processing, mineral compositions, and Carlson and Lindsley (1988) relations. In 618 all the FMC samples but Le Pouget pyroxenite, Grt grains in contact with Cpx grains undergo 
619 a later reaction leading to the local development of Pl, Opx and brown Spl (Fig. 12b), marking

620 the return of the samples into the Seiland P-T domain. P-T-t paths for FMC samples are 621 therefore summarized as follows (Fig. 12b): samples crystallized in Ariegite subfacies 622 conditions (magmatic Grt), suffered an early $\mathrm{T}$ decrease (large Cpx grains with Opx 623 exsolutions), and then underwent a concomitant $\mathrm{P}$ and $\mathrm{T}$ decrease that allowed a transition 624 towards the Seiland subfacies (testified by Opx-Spl-Pl inclusions in present-day Grt); a further 625 decrease in $\mathrm{T}$ brought the samples back into the Ariegite domain crystallizing the present-day 626 Grt that contains relics of the former Seiland stage (Opx-Spl-Pl in Grt). A final decompression 627 (or reheating) event that once again shifted some samples into the Seiland stability field.

628 A similar approach is followed to reconstruct the P-T-t evolution of the Morocco samples 629 (Fig. 12c). Grt was a liquidus phase in TAK-3 (Ariegite facies conditions; section 8.2) but was 630 absent when TAK-4 crystallized at a shallower depth. TAK-3 also contains some large Cpx 631 grains with Opx exsolutions, indicating a T decrease after crystallization. Grt currently present 632 in TAK-3 are mainly located around Spl (Fig. 2e-f) and formed by the reaction $\mathrm{Opx}+\mathrm{Spl}+\mathrm{Pl}$ $633>$ Grt+Cpx that documents the transition from the Seiland to the Ariegite subfacies (a previous 634 transition from the Ariegite facies crystallization conditions to the Seiland subfacies is not 635 documented by the mineralogy). Although TAK-4 did not crystallize in Ariegite facies 636 conditions (no liquidus Grt, but magmatic Pl), abundant and large Grt and Cpx grains 637 associated with the absence of $\mathrm{Ol}$ provide evidence of subsolidus equilibration under those 638 conditions. The presence of a small Spr rim between Spl and Grt (Fig. 2e-f) suggests that the 639 transition from Seiland to Ariegite subfacies conditions was mainly governed by a decrease in $640 \mathrm{~T}$ inducing the reaction $\mathrm{Opx}+\mathrm{Spl}+\mathrm{Pl}->\mathrm{Grt}+\mathrm{Spr}$; this is consistent with the Al-rich composition 641 of TAK-4 Opx that is required for such a reaction (France et al., 2009). Alternatively, if TAK6424 was crystallized at deep crustal levels (see section 8.2.2), the cooling stage associated with 643 this reaction may have been associated with a pressure increase. We will hereafter consider 
644 only the less complex model that necessitates only a cooling stage. The presence of numerous

645 Spr inclusions in Spl (Fig. 2e-f) and of one Spr relic surrounded by small crystals of Opx, Spl 646 and Pl within a Cpx grain (Fig. 2a) document a further reaction, namely Grt+Spr$647>\mathrm{Opx}+\mathrm{Spl}+\mathrm{Pl}$, before the sample equilibrated in the Ariegite subfacies. This reaction marks 648 the transition from the Spr-bearing Ariegite subfacies to the Spr-absent Ariegite subfacies, 649 probably in response to a decrease in P. Despite those P-T-t estimates, Spr-bearing TAK-4 650 appears to have a rather complex paragenesis evolution. Further constraints from 651 thermodynamic models will be needed to decipher a more precise evolution, however such 652 work is beyond the scope of the present study. P-T-t paths for Morocco pyroxenites are 653 therefore mostly characterized by a cooling event subsequent to crystallization that it is 654 possibly followed by a concomitant $\mathrm{P}$ and $\mathrm{T}$ decrease before re-equilibration at lower $\mathrm{T}$.

655 Pyroxenites from Cameroon contain large amounts of Cpx that exsolves Grt and sometimes 656 Opx. Grt was not a liquidus phase when these cumulates crystallized, as shown by their 657 relatively flat whole rock REE patterns (Fig. 6), constraining their formation in the Seiland 658 subfacies (Fig. 12b). As previously discussed for the FMC and Morocco samples, exsolution 659 of Opx is related to a decrease in T after crystallization. The occurrence of Grt is also related 660 to a strong cooling event when it exsolved from Cpx or crystallized around Spl while the 661 samples were moved to the Ariegite facies. This evolution can be accounted for by an isobaric $662 \mathrm{~T}$ decrease or a concomitant $\mathrm{T}$ and $\mathrm{P}$ decrease. P-T-t paths for Cameroon pyroxenites 663 therefore record a rather simple P-T-t trajectory marked mainly by a decrease in T (Fig. 12b). 664 Evolution in pressure is poorly constrained, and a slight decompression may have occurred.

665 Pyroxenites from Jordan show only limited mineralogical reactions that can be used to 666 decipher their P-T-t evolution (Fig. 12c). Pyroxenes from JO-12h are the most magnesian 667 among the studied samples, Spl contains the highest amount of $\mathrm{Cr}_{2} \mathrm{O}_{3}$, and $\sim 10 \% \mathrm{Ol}$ is 668 present; altogether those observations point to a parental melt that was slightly more primitive 
669 than for other samples. In this pyroxenite, the absence of $\mathrm{Pl}$ and the presence of

$670 \mathrm{Ol}+\mathrm{Cpx}+\mathrm{Opx}+\mathrm{Spl}$ indicates that the reaction separating the Seiland subfacies and the Pl-

671 lherzolite facies $(\mathrm{Cpx}+\mathrm{Opx}+\mathrm{Spl}->\mathrm{Ol}+\mathrm{Pl})$ has not occurred. JO-12h therefore equilibrated in

672 the Seiland subfacies. Grt was not a liquidus phase in any of the Jordan samples (Fig. 6;

673 section 8.2), also implying crystallization in the Seiland subfacies. When present, Grt appears

674 as exsolutions in pyroxene or around $\mathrm{Spl}$ (JO-7b and JO-7h), and so is clearly a subsolidus

675 mineral. Grt exsolutions in pyroxenes are also indicative of a marked cooling event from the

676 Seiland to the Ariegite field. Also consistent with an important cooling event are the

677 numerous rutile exsolution lamellae in Opx of JO-10e (Fig. 21). Indeed during crystallization

678 at high pressure, in the absence of $\mathrm{Ol}$ and $\mathrm{Spl}$, Ti is accommodated by Opx, and can be

679 exsolved to form rutile exsolution needles during cooling (Verhoogen, 1962; Moore, 1968).

680 P-T-t paths of Jordan samples are therefore mainly governed by a strong temperature decrease

681 but are not well constrained in pressure (Fig. 12c). As is the case for Cameroon samples, a

682 slight decrease in pressure may have occurred during thermal equilibration toward cooler 683 conditions (Fig. 12c).

684

685 8.5. Inter- and intra-sites variability

686 Invoking a common cumulative process for the formation of the studied pyroxenites may 687 sound odd given the inter- and intra-region petrographical and geochemical variability of the 688 samples. Nevertheless, partial crystallization of mantle derived melts during interactions with 689 peridotites at various depths has the potential to crystallize such apparently heterogeneous 690 cumulates (Downes, 2007). In particular, whole rock compositions (major and trace elements) 691 are only representative of the initial cumulative assemblage ( \pm metasomatism) that has been 692 sampled by a given xenolith (Fig. 13). An extreme case would be that a small size xenolith 693 might sample only one mineral of this initial cumulative assemblage (e.g., Cpx, Opx, Grt, Spl; 
694

695

696

697

698

699 initial cumulative assemblage as cumulates have suffered several metamorphic reactions

700 during their subsolidus evolution (Fig. 12, 13). The present day modal composition of a given

701

702

703 common genesis.

cases 1, 2, 3 in Fig. 13). A more likely case would be that a xenolith samples a poly-mineral piece of the initial cumulative assemblage (cases 4, 5 in Fig. 13). In that case, the whole rock composition represents a mixing of the mineral compositions that relies on the modal proportion within the initial cumulative assemblage (Fig. 13b-c). One striking feature is that the modal composition of a given xenolith does not represent the modal proportion of the sample is therefore not directly representative of the whole rock composition (e.g., TAK-4 contains $56 \%$ Grt when the trace element content shows that Grt was not part of the initial cumulative assemblage). The widespread metasomatic events that have affected most of the samples are expected to modify mainly the trace element budgets (e.g., LREE enrichments; samples 1, 2, 4, 5 in Fig. 13c).

Given the various crystallization pressures (Seiland versus Ariegites subfacies; Table 1), the numerous initial modal proportions that a given xenolith may sample (Fig. 13), and the range of metasomatic enrichments that can affect the samples (Fig. 13c, and section 8.3), it is likely that the samples display a strong inter- and intra-region variability, though they share a

\subsection{Geodynamic implications}

\subsubsection{Late-orogenic genesis of pyroxenites}

Petrological and geochemical evidences reported above, highlight that all the studied pyroxenite xenoliths are products of melt crystallization at mantle conditions (1-2 GPa). Similar cumulative rocks to those studied here have been recognized at Moho depth in overthickened arc crust (Burg, 2011) where they crystallized prior to the thinning and exhumation of the thickened crust. Cumulates have later undergone subsolidus evolution 


\section{Garnet Pyroxenites in Old Orogenic Regions}

719

720

721

722

723

724

under progressively changing $\mathrm{P}$ and $\mathrm{T}$ conditions; reconstructed $\mathrm{P}-\mathrm{T}-\mathrm{t}$ paths therefore also highlight the P-T-t evolution of the regional host mantle, and can be used to discuss the geodynamic settings that resulted in pyroxenite crystallization. Two P-T-t path types are observed among the samples: the first is characterized by a strong cooling event that may have been accompanied by a pressure decrease (Cameroon and Jordan samples; Fig. 12), and the second is characterized by two important cooling stages separated by a period during which $\mathrm{P}$ and T decrease jointly (FMC and Morocco samples; Fig. 12). The four studied areas have been implicated in orogenic episodes in the last $800 \mathrm{Ma}$ (either Panafrican or Hercynian). In this perspective, the crystallization of mantle melts at depth, followed by a strong decrease in $\mathrm{T}$, and then by a decompression stage, can only occur during the exhumation of an orogenic domain, and the associated thermal re-equilibration. Similar P-T paths for mantle rocks have been described in different areas (Müntener, 1997; Fabriès et al., 1998; Kaeser et al., 2009), and major magmatic episodes (e.g., magmatic underplating) are well known to occur in the late evolution of orogenic domains (e.g., Henk et al., 1997; Fabriès et al., 1998; Cottin et al., 1998; Féménias et al., 2003; Kaeser et al., 2009; McCarthy and Müntener, 2015). Along with underplating occurring at Moho depth, large circulations of melts in deeper mantle domains are expected and associated with refertilization reactions (e.g., McCarthy and Müntener, 2015). The melting event may start during the first stage of exhumation when mantle is upwelling roughly adiabatically (isostatic re-equilibration). Post-crystallization equilibration to the local geothermal $\mathrm{T}$ is recorded by the first part of the cooling stage. Following crystallization and cooling, Morocco and FMC (and possibly Cameroon and Jordan) samples underwent decompression tentatively related to the continuation of erosion and tectonic collapse of the orogenic edifices. All the studied cumulates record the late orogenic stage corresponding to the thermal re-equilibration along the continental geotherm (last cooling stage). FMC samples from the Devès volcanic field have recorded a late $\mathrm{P}$ decrease; this event 
744 could be linked to the Cenozoic bulging affecting the FMC (e.g., Sobolev et al., 1996;

745 Seranne, 1999). This is consistent with the absence of this last P drop in the southernmost

746 sample (Le Pouget), as no bulging has been described in the southern part of the FMC (e.g.,

747 Sobolev et al., 1996; Seranne, 1999).

748 The late-orogenic origin of the studied cumulates can be challenged by chronological 749 constraints; indeed $\mathrm{Nd}$ isotopic compositions can be used to put some constraints on the 750 timing of these events (e.g., Bizimis et al., 2005). Although these estimates should be 751 considered with serious caution (e.g., Wittig et al., 2006; Downes, 2007), building time 752 estimates using $\mathrm{Nd}$ in $\mathrm{Cpx}$ seems appropriate as those minerals host $\sim 80 \%$ of the whole rock 753 Nd budget (Garrido et al., 2000). Assuming that in each region the pyroxenites formed from a 754 similar melt with homogeneous isotopic composition, samples from Cameroon have 755 crystallized between 700 and 1000 Ma ago. Such an estimation is valid for Jordan 756 pyroxenites, for which the origin can be estimated between 550 and 650 Ma. Morocco 757 samples are strongly overprinted by metasomatic circulations, and although time estimates are 758 consistent with late Panafrican orogeny ( 520 Ma), those samples will not be considered here. 759 For Cameroon and Jordan, these rough time estimates correspond, with large uncertainties, to 760 the main Panafrican orogenic events affecting the crust and the upper mantle in these areas. 761 Again, these time constraints should be considered with serious caution as most of the 762 samples have been affected by post-crystallization metasomatism, which may have modified $763 \mathrm{Sm} / \mathrm{Nd}$ ratios and $\mathrm{Nd}$ isotopic compositions.

764 As a whole, the pyroxenites were formed in mantle conditions during late-orogenic 765 magmatism associated with orogenic exhumation (Fig. 14a-c). The recorded orogenic cycle is 766 probably the last main one in each region, and may be Panafrican for Jordan, Morocco and 767 Cameroon, and Hercynian for FMC. During their subsequent evolution, cumulates have 768 suffered several interactions with percolating fluids and melts. 


\subsubsection{Mantle refertilization and forthcoming magma genesis}

771 We have shown that the studied Grt pyroxenites are mantle cumulates that crystallized during

772 the relaxation following orogenic events, and subsequently underwent modal and cryptic 773 metasomatism. Pyroxenites are fertile lithologies as their solidus is crossed at lower T than the

774 lherzolite solidus; up to $15 \%$ pyroxenite partial melting can be reached before the onset of 775 lherzolite melting (Hirschmann and Stolper, 1996). The addition of a pyroxenite component in 776 a given mantle domain consequently corresponds to a refertilization stage (e.g., Bodinier et 777 al., 2008), and the presence of pyroxenitic and metasomatic lithologies in the mantle has strong implications on basalt genesis (either MORB or OIB; Allègre and Turcotte, 1986; Hirschmann and Stolper, 1996; Hirschmann et al., 2003; Kogiso et al., 2003; Kogiso et al., 780 2004; Pilet et al., 2008). The present study thus highlights that a refertilization stage of 781 lithospheric mantle can occur during the late orogenic re-equilibration period. It follows that 782 subsequent magmatic activity can be enhanced in old orogenic regions (such as FMC, 783 Morocco, Cameroon, Jordan), as it can be initiated earlier, and may be characterized by higher 784 magma volumes than in a non-affected region (Fig. 14). Nevertheless, tracking the implication 785 of such fertile lithologies in recent volcanism remains elusive as the melt-peridotite reactions that occurred during melt ascent prevent the geochemical tracking of this influence (e.g., Le Roux et al., 2009; Lambart et al., 2009).

\section{Conclusions}

790 The petrographical, geochemical, and isotopic study of garnet bearing pyroxenite xenoliths 791 from four localities (FMC, Morocco, Jordan and Cameroon) allows characterization of their 792 genesis and subsequent evolution. The whole-rock major element compositions and 793 compatible element abundances, the absence of $\mathrm{Pl}$ in the initial cumulative assemblage for all 
794 the samples (but one sample from Morocco), and mineral oxygen isotopic compositions

795 highlight a cumulative mantle origin. Metamorphic reactions, exsolutions and trace element 796 whole-rock concentrations demonstrate that crystallization pressures ranged between 1 and 2

797 GPa (30-60 km depth) depending on the samples. P-T-t paths based on well characterized 798 petrographical relations and calculated equilibrium temperatures attest to important 799 movements in the respective lithospheres, whereas the presence of some hydrous minerals 800 such as amphiboles, and incompatible element concentrations attest to a metasomatic 801 overprint in most of the samples; this metasomatic enrichment also affects the host mantle. In 802 their geodynamical context, the samples are interpreted as representing the crystallization of 803 percolating melts formed at mantle conditions during exhumation of orogenic domains. 804 Although variable due to the long-term integration of various father/daughter ratios, the $\mathrm{Sr}$ 805 and $\mathrm{Nd}$ isotope signatures are consistent with crystallization during Panafrican times for 806 Cameroon, Morocco and Jordan samples.

807 The results presented here highlight that exhumation of orogenic domains and the associated 808 sub-adiabatic decompression trigger mantle partial melting; the melt percolating the mantle 809 crystallizes, at least partially, to form the studied cumulative pyroxenites. At mantle 810 conditions, pyroxenites are low melting point lithologies; their crystallization in mantle 811 domains therefore implies its refertilization. As a consequence, the magmatism in old 812 orogenic regions such as FMC, Morocco, Cameroon and Jordan, will be enhanced, and old 813 orogenic domains would be precursor zones for magmatism that would be initiated earlier and 814 would be volumetrically larger than in non-affected areas.

\section{Acknowledgments}

817 We express our warm thanks to the various people involved at different technical stages of 818 this work: C. Bosq, and D. Auclair-Aubierge for assistance during sample preparation, and 
819 TIMS measurements; J.L. Devidal for assistance during EPMA measurements; and J.L. Piro

820 for assistance during LA-ICP-MS measurements. H. Downes, M. Wilson, and B. Ildefonse are 821 thanked for useful comments on an early version of the manuscript. Two anonymous 822 reviewers, Guilio Borghini, and the associate Editor are thanked for their constructive 823 comments that have helped to largely improve the manuscript. C. Cordier is thanked for 824 valuable discussions, and for her help for illustrations. We also thank J.C. Vilminot and D. 825 Velde, who provided us garnet pyroxenite samples from the Devès Massif, together with 826 related valuable geochemical data, J.P. Lorand for providing us Le Pouget sample from the 827 MNHN-Paris collection, and R. Temdjim who shares the Cameroon samples property with P. 828 Boivin. This is CRPG contribution $\mathrm{n}^{\circ} \mathrm{XXXX}$. 


\section{Garnet Pyroxenites in Old Orogenic Regions}

830

831

832

833

\section{$\underline{\text { References }}$}

Allègre, C.J., Turcotte, D.L., 1986. Implications of a two-component marble-cake mantle. Nature 323, 123127.

Anders, E., Grevesse, N., 1989. Abundances of elements: Meteoritic and solar. Geochimica et Cosmochimina Acta 53, 197-214.

Babkine, J., Conquere, F., Vilminot, J., 1968. Découverte d'une enclave d'ariégite à grenat dans l'absarokite du Pouget (Herault). Comptes Rendus de l'Académie des Sciences 267, 1266-1269.

Baker, J., Chazot, G., Menzies, M., Thirlwall M., 1998. Metasomatism of the shallow mantle beneath Yemen by the Afar Plume-Implications for mantle plumes, flood volcanism, and intraplate volcanism. Geology 26, 431-434. doi:10.1130/0091-7613(1998)026<0431:MOTSMB>2.3.CO;2.

Ballentine, C.J., Lee, D.C., Halliday, A.N., 1997. Hafnium isotopic studies of the Cameroon line and new HIMU paradoxes. Chemical Geology 139, 111-124.

Bertrand, H., Chazot, G., Blichert-Toft, J., Thoral, S., 2003. Implications of widespread HIMU volcanism on the Arabian Plate for the composition of the Afar mantle plume and lithoshere. Chemical Geology 198, 47-61. Bizimis, M., Sen, G., Salters, V.J.M., Keshav, S., 2005. Hf-Nd-Sr isotope systematics of garnet pyroxenites from salt lake crater, Oahu, Hawaii: Evidence for a depleted component in Hawaiian volcanism. Geochimica et Cosmochimina Acta 69-10, 2629-2646.

Blusztajn, J., Hart, S.R., Shimizu, N., McGuire, A.V., 1995. Trace-element and isotopic characteristics of spinel peridotite xenoliths from Saudi Arabia. Chemical Geology 123, 53-65.

Bodinier, J.L., Garrido, C.J., Chanefo, I., Bruguier, O., Gervilla, F., 2008. Origin of Pyroxenite-Peridotite Veined Mantle by Refertilization Reactions: Evidence from the Ronda Peridotite (Southern Spain). Journal of Petrology 49(5), 999-1025. doi: 10.1093/petrology/egn014.

Borghini, G., Rampone, E., Zanetti, A., Class, C., Cipriani, A., Hofmann, A.W., Goldstein, S.L., 2013. Meter-scale $\mathrm{Nd}$ isotopic heterogeneity in pyroxenite-bearing Ligurian peridotites encompasses global-scale upper mantle variability. Geology 41-10, 1055-1058.

Burg, J.P., 2011. The Asia-Kohistan-India collision: Review and discussion. In: Arc-continent collision. Brown, D., Ryan, P.D., (Editors), Springer-Verlag, Berlin, 279-309, http://dx.doi.org/10.1007/978-3-540$\underline{88558-0}$

Caldeira, R., Munha, J.M., 2002. Petrology of ultramafic nodules from São Tomé Island, Cameroon Volcanic Line (oceanic sector). Journal of African Earth Sciences 34, 231-246. 


\section{Garnet Pyroxenites in Old Orogenic Regions}

860 Cantagrel, J.M., Jamond, C., Lassere, M., 1978. Le magmatisme alcalin de la Ligne du Cameroun au Tertiaire

861 inférieur, données géochronologiques K/Ar. C. R. Somm. Soc. Géol. France 6, 300-303.

862 Carlson, W.D., Lindsley, D.H., 1988. Thermochemistry of pyroxenes on the join $\mathrm{Mg}_{2} \mathrm{Si}_{2} \mathrm{O}_{6}-\mathrm{CaMgSi}_{2} \mathrm{O}_{6}$. 863 American Mineralogist 73, 242-252.

864 Castaing, C., Feybesse, J.L., Thiéblemont, D., Triboulet, C., Chèvremont, P., 1994. Palaeogeographical 865 reconstructions of the Pan-African/Brasiliano orogen: closure of an oceanic domain or intracontinental convergence between major blocks? Precambrian Research 69, 327-344.

867 Chazot, G., Menzies, M.A., Harte, B., 1996. Determination of partition coefficients between apatite, clinopyroxene, amphibole and melt in natural spinel lherzolites from Yemen: Implications for wet melting of the lithospheric mantle. Geochimica et Cosmochimica Acta 60, 423-437.

870 Chazot, G., Lowry, D., Menzies, M., Mattey, D., 1997. Oxygen isotopic composition of hydrous and anhydrous mantle peridotites. Geochimica et Cosmochimica Acta 61, 161-169.

872 Cottin, J.Y., Lorand, J.P., Agrinier, P., Bodinier, J.L., Liégeois, J.P., 1998. Isotopic (O, Sr, Nd) and trace element geochemistry of the Laouni layered intrusions (Pan-African belt, Hoggar, Algeria): evidence for postcollisional continental tholeiitic magmas variably contaminated by continental crust. Lithos 45, 197-222.

Dautria, J.M., Liotard, J.M., Bosch, D., Alard, O., 2010. 160 Ma of sporadic basaltic activity on the Languedoc volcanic line (Southen France): A peculiar case of lithosphere-asthenosphere interplay. Lithos 120, 202222.

Downes, H., Reichow, M.K., Mason, P.R.D., Beard, A.D., Thirlwall, M.F., 2003. Mantle domains in the lithosphere beneath the French Massif Central: trace element and isotopic evidence from mantle clinopyroxenes. Chemical Geology 200, 71-87.

881 Downes, H., 2007. Origin and significance of spinel and garnet pyroxenites in the shallow lithospheric 882 mantle: Ultramafic massifs in orogenic belts in Western Europe and NW Africa. Lithos 99: 1-24.

883 Droop, G.T.R., 1987. A general equation for estimating $\mathrm{Fe}^{3+}$ concentrations in ferromagnesian silicates and oxides from microprobe analyses, using stoichiometric criteria. Mineralogical Magazine 51, 431-435.

885 El Azzouzi, M., Bernard- Griffiths, J., Bellon, H., Maury, R. C., Piqué, A., Fourcade, S., Cotten, J., Hernandez, J., 1999. Evolution des sources du volcanisme marocain au cours du Néogène. Comptes Rendus de 887 l'Académie des Sciences de Paris, Sciences de la Terre et des Planètes 329, 95-102. 


\section{Garnet Pyroxenites in Old Orogenic Regions}

888 El Azzouzi, M., Maury, R., Bellon, H., Youbi, N., Cotten, J., Kharbouch, F., 2010. Petrology and K-Ar chronology of the Neogene-Quaternary Middle Atlas basaltic province Morocco. Bulletin de la Société Géologique de France 181, 243-257.

891 Fabriès, J., Figueroa, O., Lorand, J.P., 1987. Petrology and thermal history of highly deformed mantle 892 xenoliths from the Montferrier basanites, Languedoc, southern France: A comparison with Ultramafic 893 Complexes from the north Pyrenean Zone. Journal of Petrology 28, 887-919.

894 Fabriès, J., Lorand, J.P., Bodinier, J.L., 1998. Petrogenetic evolution of orogenic lherzolite massifs in the 895 central and western Pyrenees. Tectonophysics 292, 145-167.

896 Féménias, O., Coussaert, N., Bingen, B., Whitehouse, M., Mercier, J.C.C., Demaiffe, D., 2003. A Permian underplating event in the late- to post-orogenic tectonic setting. Evidence from the mafic-ultramafic layered xenoliths from Beaunit (French Massif Central). Chemical Geology 199, 293-315.

899 France, L., Nicollet, C., 2010. MetaRep, an extended CMAS 3D program to visualize mafic (CMAS, ACF-S, ACFN) and politic (AFM-K, AFM-S, AKF-S) projections. Computers \& Geosciences 36, 786-791. doi:10.1016/j.cageo.2010.01.001

902 France, L., Ouillon, N., Chazot, G., Kornprobst, J., Boivin, P., 2009. CMAS 3D a new program to rapidly visualise and project major elements compositions in the CMAS system. Computers and Geosciences 35, 1304-1310. doi:10.1016/j.cageo.2008.07.002.

905 France, L., Ildefonse, B., Koepke, J., Bech, F., 2010. A new method to estimate the oxidation state of basaltic series from microprobe analyses. Journal of Volcanology and Geothermal Research 189, 340-346. doi: 10.1016/j.jvolgeores.2009.11.23

908 France, L., Koepke, J., MacLeod, C.J., Ildefonse, B., Godard, M., Deloule, E., 2014. Contamination of MORB by anatexis of magma chamber roof rocks: constraints from a geochemical study of experimental melts and associated residues. Lithos 202-203, 120-137. doi : 10.1016/j.lithos.2014.05.018

911 Frey, F.A., 1980. The origin of pyroxenites and garnet pyroxenites from Salt Lake Crater, Oahu, Hawaii: trace element evidence. American Journal of Science 280-A, 427-449.

913 Gao, Y., Hoefs, J., Przybilla, R., Snow, J.E., 2006. A complete oxygen isotope profile through the lower oceanic 914 crust, ODP Hole 735B. Chemical Geology 233, 217-234.

915 Garrido, C.J., Bodinier, J.L., Alard, 0., 2000. Incompatible trace element partitioning and residence in 916 anhydrous spinel peridotites and websterites from the Ronda orogenic peridotite. Earth and Planetary 917 Science Letters 181, 341-358. 


\section{Garnet Pyroxenites in Old Orogenic Regions}

918 Gasquet, D., Levresse, G., Cheilletz, A., Azizi-Samir, M.R., Mouttaq, A., 2005. Contribution to a geodynamic reconstruction of the Anti-Atlas (Morocco) during Pan-African times with the emphasis on inversion tectonics and metallogenic activity at the Precambrian-Cambrian transition. Precambrian Research 140, 157-182.

Gasparik, T., 2014. Phase diagrams for geoscientists. An atlas of the Earth's inerior. Second ed., Springer New York. doi:10.1007/978-1-4614-5776-3.

Godard, M., Awaji, S., Hansen, H., Hellebrand, E., Brunelli, D., Johnson, K., Yamasaki, T., Maeda, J., Abratis, M., Christie, D., Kato, Y., Mariet, C., Rosner, M., 2009. Geochemistry of a long in-situ section of intrusive slowspread oceanic lithosphere: Results from IODP Site U1309 (Atlantis Massif, $30^{\circ} \mathrm{N}$ Mid-Atlantic-Ridge). Earth and Planetary Science Letters 279, 110-122

Goncharov, A.G., Ionov, D.A., 2012. Redox state of deep off-craton lithospheric mantle: new data from garnet and spinel peridotites from Vitim, southern Siberia. Contributions to Mineralogy and Petrology 164-5: 731-745. doi: 10.1007/s00410-012-0767-z

931 Gonzaga, R.G., Lowry, D., Jacob, D.E., LeRoex, A., Schulze, D., Menzies, M.A., 2010a. Eclogites and garnet pyroxenites: Similarities and differences. Journal of Volcanology and Geothermal Research 190, 235-247. Gonzaga, R.G., Menzies, M.A., Thirlwall, M.F., Jacob, D.E., LeRoex, A., 2010b. Eclogites and Garnet pyroxenites: Problems resolving provenance using Lu-Hf, Sm-Nd and Rb-Sr Isotope systems. Journal of Petrology $51(1-2), 513-535$.

Granet, M., Wilson, M., Achauer, U., 1995. Imaging a mantle plume beneath the French Massif Central. Earth and Planetary Science Letters 136, 281-296.

938 Green, D.H., Ringwood, A.E., 1967. The genesis of basaltic magmas. Contributions to Mineralogy and 939 Petrology 15, 103-190.

940 Gregory, R.T., Taylor, H.P., 1981. An Oxygen Isotope Profile in a Section of Cretaceous Oceanic Crust, Samail 941 Ophiolite, Oman: Evidence for $\delta^{18} 0$ Buffering of the Oceans by Deep (5 km) Seawater-Hydrothermal 942 Circulation at Mid-Ocean. Journal of Geophysical Research 86-B4, 2737-2755.

943 Griffin, W.L., O’Reilly, S., 2007. Cratonic lithospheric mantle : Is anything subducted? Episodes 30(1), 43-53

944 Halliday, A.N., Dickin, A.P., Fallick, A.E., Fitton, J.G., 1988. Mantle dynamics: a Nd, Sr, Pb and O isotopic study 945 of the Cameroon line volcanic chain. Journal of Petrology 29, 181-211.

946 Hart, S. R., Hauri, E. H., Oschmann, L. A., Whitehead J. A., 1992. Mantle plumes and entrainment: isotopic evidence. Science 256, 517-520. 


\section{Garnet Pyroxenites in Old Orogenic Regions}

948 Harte, B., Kirkley, M.B., 1997. Partitioning of trace elements between clinopyroxene and garnet: data from

949 mantle eclogites. Chemical Geology 136, 1-24

950 Haüy, R.-J., 1822. Traité de minéralogie, 2nd éd. Bachelier et Huzard, Paris.

951 Heinonen, J.S., Luttinen, A.V., Riley, T.R., Michallik, R.M., 2013. Mixed pyroxenite-peridotite sources for mafic 952 and ultramafic dikes from the Antarctic segment of the Karoo continental flood basalt province. Lithos $953177,366-380$.

954 Henjes-Kunst, F., Altherr, R., Baumann, A., 1990. Evolution and composition of the lithospheric mantle underneath the western Arabian peninsula: constraints from Sr-Nd isotope systematics of mantle xenoliths. Contributions to Mineralogy and Petrology 105, 460-472.

957 Henk, A., Franz, L., Teufel, S., Oncken, O., 1997. Magmatic underplating, extension, and crustal reequilibration: Insights from a cross-section through the Ivrea zone and Strona-Ceneri Zone, Northern Italy. The Journal of Geology 105, 367-377.

960 Hirschmann, M.M., Stolper, E.M., 1996. A possible role for garnet pyroxenites in the origin of the 'garnet signature' in MORB. Contributions to Mineralogy and Petrology 124, 185-208.

962 Hirschmann, M.M., Kogiso, T., Baker, M.B., Stolper, E.M., 2003. Alkalic magmas generated by partial melting of garnet pyroxenite. Geology 31(6), 481-484

964 Huang, X.L., Xu, Y.G., Lo, C.H., Wang, R.C., Lin, C.Y., 2007. Exsolution lamellae in a clinopyroxene megacryst aggregate from Cenozoic basalt, Leizhou Peninsula, South China: petrography and chemical evolution. Contributions to Mineralogy and Petrology 154, 691-705.

967 Ionov, D.A., Harmon, R.S., France-Lanord, C., Greenwood, P.B., Ashchepkov, I.V., 1994. Oxygen isotope 968 composition of garnet and spinel peridotites in the continental mantle: Evidence from the Vitim xenolith suite, southern Siberia. Geochimica et Cosmochimica Acta 58, 1463-1470.

970 Johnson, K.T.M., 1994. Experimental cpx/and garnet/melt partitioning of REE and other trace elements at 971 high pressures: petrogenetic implications. Mineralogical Magazine 58A, 454-455

972 Johnson, K.T.M., Dick, H.J.B., Shimizu, N., 1990. Melting in the oceanic upper mantle; an ion microprobe study 973 of diopsides in abyssal peridotites. Journal of Geophysical Research 95, 2661-2678.

974 Juvigné, E., Bastin, B., Delibrias, G., Evin, J., Gewelt, M., Gilot, E., Streel, M., 1996. A comprehensive pollen and 975 tephra-based chronostratigraphic model for the Late-glacial and Holocene period in the French MassifCentral. Quaternary International 34-36, 113-120. 


\section{Garnet Pyroxenites in Old Orogenic Regions}

977 Kaeser, B., Olker, B., Kalt, A., Altherr, R., Pettke, T., 2009. Pyroxenite xenoliths from Marsabit (Northern

978 Kenya): evidence for different magmatic events in the lithospheric mantle and interaction between

979 peridotite and pyroxenite. Contributions to Mineralogy and Petrology 157, 453-472.

980 Kamgang, P., Chazot, G., Njonfang, E., Tchoua, F., 2008. Geochemistry and geochronology of mafic rocks from

981 Bamenda Mountains (Cameroon): Source composition and crustal contamination along the Cameroon

982 Volcanic Line. C. R. Geosciences 340, 850-857.

983 Kogiso, T., Hirschmann, M.M., Frost, D.J., 2003. High-pressure partial melting of garnet pyroxenite: possible 984 mafic lithologies in the source of ocean island basalts. Earth and Planetary Science Letters 216(4), 603617

986 Kogiso, T., Hirschmann, M.M., Pertermann, M., 2004. High-pressure Partial Melting of Mafic Lithologies in the Mantle. Journal of Petrology 45-12, 2407-2422.

988 Kornprobst, J., 1969. Le massif ultramafique des Beni Bouchera (Rif interne, Maroc): Etude des péridotites 989 de haute temperature et de haute pression et des pyroxenolites, à grenat ou sans grenat, qui leur sont associées. Contributions to Mineralogy and Petrology 23, 283-322.

991 Krienitz, M. S., Haase, K. M., Mezger, K., Van den Bogaard, P., Thiemann, V., Shaikh-Mashail M. A., 2009. Tectonic events, continental intraplate volcanism, and mantle plume activity in northern Arabia:

993 Constraints from geochemistry and Ar-Ar dating of Syrian lavas. Geochemistry, Geophysics, Geosystems 10, Q04008, doi:10.1029/2008GC002254.

995 Krienitz, M-S. and Haase, K.M., 2011. The evolution of the Arabian lower crust and lithospheric mantle Geochemical constraints from southern Syrian mafic and ultramafic xenoliths. Chemical Geology 280, 271-283.

998 Lambart, S., Laporte, D., Schiano, P., 2009. An experimental study of pyroxenite partial melts at 1 and 1.5 GPa: Implications for the major-element composition of Mid-Ocean Ridge Basalts. Earth and Planetary Science Letters 288, 335-347.

Lasserre, M., Tempier, P., Soba, D., 1981. Pétrographie et géochronologie Rb/Sr des granites cambriens de Goutchoumi et d'Anloa (Cameroun). Bulletin de la Société Géologique de France 23, 511-514.

1003 Le Bas, M.J., Streckeisen, A.L., 1991. The IUGS systematics of igneous rocks. Journal of the Geological Society, $1004 \quad$ London 148, 825-833.

1005 Le Roux, V., Bodinier, J.L., Alard, O., O'Reilly, S.Y., Griffin, W.L., 2009. Isotopic decoupling during porous melt 1006 flow: A case-study in the Lherz peridotite. Earth and Planetary Science Letters 279, 76-85. 


\section{Garnet Pyroxenites in Old Orogenic Regions}

1007 Lee, D. C., Halliday, A. N., Fitton, J. G., Poli, G., 1994. Isotopic variations with distance and time in the volcanic

1008

1009

1010

1011

1012

1013

1014

1015

1016

1017

1018

1019

1020

1021

1022

1023

1024

1025

1026

1027

1028

1029

1030

1031

1032

1033

1034 islands of the Cameroon line: Evidence for a mantle plume origin. Earth and Planetary Science Letters $123,119-138$

Lee, D. C., Halliday, A. N., Davies, G. R., Essene, E. J., Fitton, J. G., Temdjim, R., 1996. Melt enrichment of shallow depleted mantle: A detailed petrological, trace element and isotopic study of mantle derived xenoliths and megacrysts from the Cameroon Line. Journal of Petrology 38, 415-441.

Lenoir, X., Garrido, C.J., Bodinier, J.L., Dautria J.M., 2000. Contrasting domains beneath the Massif Central (France) revealed by geochemistry of peridotites xenoliths. Earth and Planetary Science Letters 181, $359-375$.

Liang, Y., Sun, C., Yao, L., 2013. A REE-in-two-pyroxene thermometer for mafic and ultramafic rocks. Geochimica et Cosmochimica Acta 102, 246-260.

Liu, T.C., Presnall, D.C., 2000. Liquidus phase relations in the system $\mathrm{CaO}-\mathrm{MgO}-\mathrm{Al}_{2} \mathrm{O}_{3}-\mathrm{SiO}_{2}$ at $2.0 \mathrm{GPa}$ : applications to basalt fractionation, eclogites, and igneous Sapphirine. Journal of Petrology 41, 3-20.

Marchesi, C., Garrido, C.J., Bosch, D., Bodinier, J.L., Gervilla, F., Hidas, K., 2013. Mantle refertilization by melts of crustal-derived garnet pyroxenite: Evidence from the Ronda peridotite massif, southern Spain. Earth and Planetary Science Letters 362, 66-75.

Marzoli, A., Piccirillo, E.M., Renne, P.R., Bellieni, C., Iacumin, M., Nyobe, J.B., Tongwa, A.T., 2000. The Cameroon Volcanic Line Revisited: Petrogenesis of Continental Basaltic Magmas from Lithospheric and Asthenospheric Mantle Sources. Journal of Petrology 41, 87-109.

Mattey, D., Lowry, D., Macpherson, C., 1994a. Oxygen isotope composition of mantle peridotite. Earth and Planetary Science Letters 128, 231-241.

Mattey, D., Lowry, D., Macpherson, C., Chazot, G., 1994b. Oxygen isotope composition of mantle minerals by laser fluorination analysis: homogeneity in peridotites, heterogeneity in eclogites. Mineralogical Magazine 58A, 573-574.

McCarthy, A., Müntener, O., 2015. Ancient depletion and mantle heterogeneity: Revisiting the PermianJurassic paradox of Alpine peridotites. Geology, doi: 10.1130/G36340.1

Merle, O., Michon, L., 2001. The formation of the West European rift: a new model as exemplified by the Massif Central area. Bulletin Société Géologique de France 172, 213-221. 


\section{Garnet Pyroxenites in Old Orogenic Regions}

1035 Montanini, A., Tribuzio, R., Anczkiewicz, R., 2006. Exhumation history of a garnet pyroxenite-bearing mantle

1036 section from a continent-ocean transition (Northern Apennine ophiolites, Italy). Journal of Petrology 47-

1037 10: 1943-1971.

1038 Montanini, A., Tribuzio, R., Thirlwall, M., 2012. Garnet clinopyroxenite layers from the mantle sequences of 1039 the Northern Apennine ophiolite (Italy): Evidence for recycling of crustal material. Earth and Planetary $1040 \quad$ Science Letters 351-352, 171-181

1041 Moore, A., 1968. Rutile exsolution in Orthopyroxene. Contributions to Mineralogy and Petrology 17, 2331042236.

1043 Müntener, O., 1997. The Malenco peridotites (Alps). Petrology and geochemistry of subcontinental mantle 1044 and Jurassic exhumation during rifting Ph.D. Thesis, ETH Zürich.

1045 Natali, C., Beccaluva, L., Bianchini, G., Ellam, R.M., Siena, F. and Stuart, F.M., 2013. Carbonated alkali-silicate 1046 metasomatism in the North Africa lithosphere: Evidence from Middle Atlas spinel-lherzolites, Morocco. 1047 Journal of African Earth Sciences 41, 113-121.

1048 Nehlig, P., Boivin, P., de Herve A.D.G., Mergoil, J., Prouteau, G., Thiéblemont D., 2001. Les volcans du Massif 1049 Central. Géologues 130-131, 66-91.

1050 Nimis, P., Grütter, H., 2010. Internally consistent geothermometers for garnet peridotites and pyroxenites. 1051 Contributions to Mineralogy and Petrology 159, 411-427. doi: 10.1007/s00410-009-04555-9.

1052 O’Hara, M.J., 1967. Mineral facies in ultrabasic rocks. In: Ultramafic and related rocks, P.J. Wyllie ed., 7-18.

1053 O'Hara, M.J., Yoder, H.S.Jr., 1967. Formation and fractionation of basic magmas at high pressure. Scott. J. 1054 Geol. 3, 67-117.

1055 Pearson, D.G., Davies, G.R., Nixon, P.H., 1993. Geochemical Constraints on the petrogenesis of the diamond 1056 facies pyroxénites from the Beni Bousera peridotite massif, north Morocco. Journal of Petrology 34, 125$1057 \quad 172$.

1058 Pearson, D.G., Canil, D., Shirey, S.B., 2005. Mantle samples included in volcanic rocks: xenoliths and 1059 diamonds. In: Carlson, R.W. (Ed.), The Mantle and Core, vol. 2. Elsevier, pp. 171-275

1060 Perinelli, C., Armienti, P., Dallai, L., 2011. Thermal evolution of the lithosphere in a rift environment as 1061 inferred from the geochemistry of mantle cumulates, Northern Victoria Land, Antarctica. Journal of 1062 Petrology 52-4: 665-690. 


\section{Garnet Pyroxenites in Old Orogenic Regions}

1063 Pertermann, M., Hirschmann, M.M., 2003. Partial melting experiments on a MORB-like pyroxenite between 2

1064 and $3 \mathrm{GPa}$ : constraints on the presence of pyroxenite in basalt source regions from solidus location and

1065 melting rate. Journal of Geophysical Research 108 (B2), 2125. doi:10.1029/2000JB000118.

1066 Pezzali, I., France, L., Chazot, G., Vannucci, R., 2015. Analogues of exhumed pyroxenite layers in the Alboran

1067 domain sampled as xenoliths by Middle Atlas Cenozoic volcanism. Lithos.

1068 doi:10.1016/j.lithos.2015.02.024

1069 Pilet, S., Baker, M.B., Stolper, E.M., 2008. Metasomatized Lithosphere and the Origin of Alkaline Lavas.

$1070 \quad$ Science 320(5878), 916-919

1071 Pique A., Michard, A., 1989. Moroccan Hercynides; a synopsis; the Paleozoic sedimentary and tectonic

1072 evolution at the northern margin of West Africa. American Journal of Science 289, 286-330.

1073 Raffone, N., Chazot, G., Pin, C., Vannucci, R., Zanneti, A., 2009. Metasomatism in the Lithospheric Mantle

1074 beneath Middle Atlas (Morocco) and the Origin of Fe- and Mg-rich Wehrlites. Journal of Petrology 50,

1075 197-249.

1076 Rankenburg, K., Lassiter, J.C., Brey, G., 2005. The role of continental crust and lithospheric mantle in the 1077 genesis of Cameroon Volcanic Line lavas: constraints from isotopic variations in lavas and megacrysts from the Biu and Jos plateaux. Journal of Petrology 46, 169-190.

1079 Rubin, K.H., Sinton, J.M., 2007. Inferences on mid-ocean ridge thermal and magmatic structure from MORB compositions. Earth and Planetary Science Letters 260: 257-276. doi: 10.1016/j.epsl.2007.05.035

1081 Seranne, M., 1999. The Gulf of Lion continental margin (NW Mediterranean) revisited by IBS: an overview. In: Durand, B., Jolivet, L. Horvath, F. \& Seranne, M. (eds) The Mediterranean Basins: Tertiary Extension within the Alpine Orogen. Geological Society, London, Special Publications 156, 15-36.

1084 Shaw, J. E., Baker, J. A., Menzies, M. A., Thirlwall, M. F., Ibrahim K. M., 2003. Petrogenesis of the largest 1085 intraplate volcanic field on the Arabian Plate (Jordan): A mixed lithosphere-asthenosphere source 1086 activated by lithospheric extension. Journal of Petrology 44, 1657-1679, doi:10.1093/petrology/egg052

1087 Shaw, J. E., Baker, J. A., Kent, A.J.R., Ibrahim K. M., Menzies, M. A., 2007. The geochemistry of the Arabian 1088 lithospheric mantle-a source for intraplate volcanism? Journal of Petrology 48-8, 1495-1512, doi:10.1093/petrology/egm027

1090 Sobolev, S.V., Zeyen, H., Stoll, G., Werling, F., Altherr, R., Fuchs, K., 1996. Upper mantle temperatures from 1091 teleseismic tomography of French Massif Central including effects of composition, mineral reactions, 1092 anharmonicity, anelasticity and partial melt. Earth and Planetary Science Letters 139, 147-163. 


\section{Garnet Pyroxenites in Old Orogenic Regions}

1093 Sobolev, A. V., Hofmann, A. W., Sobolev, S. V., Nikogosian, I. K., 2005. An olivine-free mantle source of 1094 Hawaiian shield basalts. Nature 434(7033), 590-597.

1095 Stein, M., Goldstein, S.L., 1996. From plume head to continental lithosphere in the Arabian-Nubian shield. $1096 \quad$ Nature 382, 773-778.

1097 Stein, M., Garfunkel, Z., Jagoutz, E., 1993. Chronothermometry of peridotitic and pyroxenitic xenoliths: 1098 Implications for the thermal evolution of the Arabian lithosphere. Geochimica et Cosmochimica Acta 57, $1099 \quad 1325-1337$.

1100 Streckeisen, A.L., 1976. To each plutonic rock its proper name. Earth Sci. Rev. 12: 1-33.

1101 Takazawa, E., Frey, F.A., Shimizu, N., Obata, M., 1996. Evolution of the Horoman peridotite (Hokkaido, 1102 Japan); implications from pyroxene compositions. Chemical Geology 134, 3-26.

1103 Taylor, W.R., 1998. An experimental test of some geothermometer and geobarometer formulations for 1104 upper mantle peridotites with application to the thermobarometry of fertile lherzolites and garnet 1105 websterite. Neues Jahrbuch für Mineralogie Abhandlungen 172, 381-408.

1106 Temdjim, R., 2006. Contribution à la connaissance du manteau supérieur du Cameroun au travers de l'étude 1107 des enclaves ultrabasiques et basiques remontées par les volcans de Youkou (Adamaoua) et de Nyos 1108 (Ligne du Cameroun). Thesis, Université de Yaoundé 1 ; IRD, Yaoundé (CMR) ; Clermont-Ferrand, 423 p.

1109 Temdjim, R., Boivin, P., Chazot, G., Robin, C., Rouleau, E., 2004. L’hétérogénéité du manteau supérieur à 1110 l'aplomb du volcan de Nyos (Cameroun) révélée par les enclaves ultrabasiques. Comptes Rendus 1111 Geoscience 336, 1239-1244.

1112 Verhoogen, J., 1962. Distribution of titanium between silicates and oxides in igneous rocks. American 1113 Journal of Science 260, 211-220.

1114 Viljoen, K.S., Schulze, D.J., Quadling, A.G., 2005. Contrasting Group I and Group II eclogite xenoliths 1115 petrogenesis: Petrological, trace element and isotopic evidence from eclogite, garnet-websterite and 1116 alkremite xenoliths in the Kaalvallei kimberlite, South Africa. Journal of Petrology 46, 2059-2090.

1117 Wittig, N., Baker, J.A., Downes, H., 2006. Dating the mantle roots of young continental crust. Geology 34, 237-

$1118 \quad$ 240. doi: $10.1130 / G 22135.1$

1119 Wittig, N., Baker, J.A., Downes, H., 2007. U-Th-Pb and Lu-Hf isotopic constraints on the evolution of 1120 subcontinental lithospheric mantle, French Massif Central. Geochimica et Cosmochimica Acta 71, 129011211311. 


\section{Garnet Pyroxenites in Old Orogenic Regions}

1122 Wittig, N., Pearson, D.G., Baker, J.A., Duggen, S., Hoernle, K., 2010. A major element, PGE and Re-Os isotope study of Middle Atlas (Morocco) peridotite xenoliths: Evidence for coupled introduction of metasomatic

1124 sulphides and clinopyroxene. Lithos, 115, 15-26.

1125 Workman, R.K., Hart, S. R., 2005. Major and trace element composition of the depleted MORB mantle (DMM). 1126 Earth and Planetary Science Letters 231, 53-72.

1127 Wu, C.M., Zhao, G.C., 2012. Reply to comment on "The applicability of garnet-orthopyroxene geobarometry 1128 in mantle xenoliths" by Paolo Nimis and Herman Grütter. Lithos 142-143, 288-299

1129 Zangana, N.A., Downes, H., Thirlwall, M.F., Hegner, E., 1997. Relationship between deformation, equilibration 1130 temperatures, REE and radiogenic isotopes in mantle xenoliths (Ray Pic, Massif Central, France): an 1131 example of plume-lithosphere interaction? Contributions to Mineralogy and Petrology 127, 187-203

1132 Zheng, Y.F., 1993. Calculation of oxygen isotope fractionation in anhydrous silicate minerals. Geochimica et 1133 Cosmochimica Acta 57, 1079-1091

1134 Zhang, H.F., Mattey, D.P., Grassineau, N., Lowry, D., Brownless, M., Gurney, J.J., Menzies M.A., 2000. Recent 1135 fluid processes in the Kaapvaal Craton, South Africa: coupled oxygen isotope and trace element 1136 disequilibrium in polymict peridotites. Earth and Planetary Science Letters 176, 57-72.

1137 Zindler, A., Hart, S., 1986. Chemical geodynamics. Annual Reviews of Earth and Planetary Sciences 14, 4931138 571. 
1140

1141

1142 Figure 1: Simplified maps and sampling localities (red stars) for FMC samples (a, modified

1143 after Wittig et al., 2007), Cameroon samples (b, modified after Temdjim et al., 2004),

1144 Morocco samples (c, modified after Wittig et al., 2010), and Jordan samples (d, modified after

1145 Shaw et al., 2007).

1146

1147 Figure 2: Photomicrographs of the studied samples. a) Pl inclusion with radial fractures in the

1148 host garnet (FMC; sample LN-78; plane-polarized light); b) Green-Spl inclusion with radial

1149 fractures in host Grt; Grt grains are rimmed by a brown kelyphite displaying a Pl-Opx-Spl

1150 intergrowth (FMC; sample LN-78; plane-polarized light); c) Large Cpx porphyroclast with

1151 Opx exsolutions (FMC; sample LN-78; cross-polarized light); d) Small Opx-brown-Spl-P1

1152 association at the contact of Grt+Cpx. Green-Spl inclusions are observed in Grt. Grt are

1153 rimmed by a thin brown kelyphite displaying a Pl-Opx-Spl intergrowth (FMC; sample LN-

1154 78; plane-polarized light); e-f) Association of Grt, Cpx, Spl, and Spr in the Morocco sample

1155 TAK-4. Grt is highly kelyphitized (brown). Spr rims the Spl grains included in Grt, and is

1156 present as inclusions in Spl grains (e: plane-polarized light; f: cross-polarized light). g) RGB

1157 image of a composite inclusion in a Cpx of the Morocco sample TAK-4; it is composed of

1158 Spr, Spl, $\mathrm{Pl}$ and Opx. Colors are: $\mathrm{R}=\mathrm{Si}+\mathrm{Mg}+\mathrm{Al}, \mathrm{G}=\mathrm{Si}+\mathrm{K}+\mathrm{Mg}, \mathrm{B}=\mathrm{K}$, (blue areas are altered

1159 and composed of zeolites); h) Modal image of sample YK-01 from Cameroon. Spl (blue) is

1160 rimed by Grt (pink). Grt is also exsolved from Cpx (green) megacrysts. Photomicrographs of

1161 thin section (i; cross-polarized light) and modal image (j) of YK-05 sample from Cameroon.

1162 Note the deformation of Cpx (green in (j)) grains that is highlighted by different polarization

1163 levels (i) and by the Opx (yellow in (j)) and Grt (pink in (j)) exsolutions. k) Sample JO-7b

1164 from Jordan; Cpx, Opx, green-Spl and Grt are observed, the Grt forms small white grains and 
1165 brownish kelyphite around Spl grains. l) Photomicrograph (cross-polarized light) of an Opx

1166 grain in sample JO-10e from Jordan; the Opx is extinct and contains rutile exsolutions in two 1167 crystallographic directions.

1169 Figure 3: Mineral chemistry. a) $\mathrm{Cpx}$ and Opx compositions in molar proportions (Wo:

1170 wollastonite component; En: enstatite component; Fs: ferrosilite component). b) Grt 1171 compositions in molar proportions (Alm: almandine; Spess: spessartine; Grs: grossular; And: 1172 andradite). Open squares: Cameroon samples; filled squares: Jordan samples; open circles:

1173 French Massif-Central samples; filled circles: Morocco.

Figure 4: Chondrite-normalized (Anders and Grevesse, 1989) REE (a, c, e), and trace

1176 element (b, d, f) spider diagrams for Cpx, and Grt (Table 3). a-b) Cpx from French Massif1177 Central and Morocco samples, c-d) Cpx from Cameroon and Jordan samples, e-f) Grt for all 1178 samples.

1180 Figure 5: Whole rock major element and Ni composition diagrams (Table 4). In all diagrams, 1181 mineral composition fields are added. The dashed lines highlight correlations. Red star 1182 represents the composition of primitive MORB taken as one composition of possible trapped 1183 melt (MORB composition is taken from Rubin and Sinton, 2007; an average of 3092 data 1184 points from slow spreading ridges is used as those melts are less affected by the various 1185 processes that may occur at crustal levels in fast spreading settings, e.g., France et al., 2014); 1186 composition (in wt \%) is $\mathrm{SiO}_{2}=50.77 ; \mathrm{TiO}_{2}=1.38 ; \mathrm{Al}_{2} \mathrm{O}_{3}=15.37 ; \mathrm{FeO}_{\mathrm{T}}=9.60 ; \mathrm{MgO}=7.79$; $1187 \mathrm{CaO}=11.71 ; \mathrm{Na}_{2} \mathrm{O}=2.45 ; \mathrm{K}_{2} \mathrm{O}=0.19 ; \mathrm{P}_{2} \mathrm{O}_{5}=0.15$. Green star represents the composition of 1188 primitive alkaline basanite from Ethiopia taken as one composition of possible trapped melt 1189 (R. Pik personal communication, unpublished data); composition (in wt \%) is $\mathrm{SiO}_{2}=43.5$; 
$1190 \mathrm{TiO}_{2}=2.6 ; \mathrm{Al}_{2} \mathrm{O}_{3}=12.5 ; \mathrm{FeO}_{\mathrm{T}}=11.0 ; \mathrm{MgO}=10.4 ; \mathrm{CaO}=11.9 ; \mathrm{Na}_{2} \mathrm{O}=2.5 ; \mathrm{K}_{2} \mathrm{O}=1.0 ; \mathrm{P}_{2} \mathrm{O}_{5}=0.5$.

1191 Trapped melt seems to influence the $\mathrm{Na}_{2} \mathrm{O}$ content for some samples.

1192

1193 Figure 6: Chondrite-normalized (Anders and Grevesse, 1989) REE (a, c, e) and trace element

1194 (b, d, f) spider diagrams for whole-rock pyroxenites. a-b) French Massif-Central and 1195 Morocco samples, c-d) Cameroon samples, e-f) Jordan samples.

1196

1197 Figure 7: ${ }^{143} \mathrm{Nd} /{ }^{144} \mathrm{Nd}$ versus ${ }^{87} \mathrm{Sr} /{ }^{86} \mathrm{Sr}$ for clinopyroxene separates from Morocco, Jordan, and 1198 Cameroon. Data for DMM $\left({ }^{143} \mathrm{Nd} /{ }^{144} \mathrm{Nd}=0.51313, \quad{ }^{87} \mathrm{Sr} /{ }^{86} \mathrm{Sr}=0.70263\right)$, and BSE $1199\left({ }^{143} \mathrm{Nd} /{ }^{144} \mathrm{Nd}=0.512638,{ }^{87} \mathrm{Sr} /{ }^{86} \mathrm{Sr}=0.7045\right)$ are from Workman and Hart (2005), and for HIMU $1200\left({ }^{143} \mathrm{Nd} /{ }^{144} \mathrm{Nd}=0.51285,{ }^{87} \mathrm{Sr} /{ }^{86} \mathrm{Sr}=0.70285\right)$ from Hart et al. (1992). Data are compared to 1201 regional mantle compositions (i.e., mantle xenoliths) in a), and to regional lava compositions 1202 in b). Literature data: Mantle rocks (a) from Jordan (Henjes-Kunst et al., 1990; Stein et al., 1203 1993; Blusztajn et al., 1995; Baker et al., 1998), Morocco (Raffone et al., 2009), and 1204 Cameroon (Lee et al., 1996); and lava compositions (b) from Morocco (El Azzouzi et al., 1205 1999), Cameroon (Halliday et al., 1988; Lee et al., 1994; Ballentine et al., 1997; Marzoli et 1206 al., 2000; Rankenburg et al., 2005; Kamgang et al., 2008), Jordan (Shaw et al., 2003; Krienitz 1207 et al., 2009).

1208

1209 Figure 8: Oxygen isotopic composition of the constituent minerals in the studied pyroxenites, $1210 \delta^{18} \mathrm{O}$ is expressed in \%o. Oxygen isotopic composition of corresponding minerals in peridotites 1211 are indicated for comparison (Ionov et al., 1994; Mattey et al., 1994a; Chazot et al., 1997; 1212 Zhang et al., 2000). 
1215 Figure 9: Redox conditions. Details about calculations are given in text, and values are 1216 documented in Table S1.

1217

1218 Figure 10: Partitioning $\left(\mathrm{K}_{\mathrm{D}}\right)$ of trace elements between $\mathrm{Cpx}$ and Grt, and between $\mathrm{Cpx}$ and 1219 Opx. Blue dots represent results of $\mathbf{K}_{\mathbf{D}(\mathbf{C p x}-\mathbf{G r t})}$ calculations accounting for mineral 1220 compositions using the method of Harte and Kirkley (1997). Also shown are data of Johnson 1221 (1994), Viljoen et al. (2005), Huang et al. (2007), and Raffone et al. (2009) for comparison.

Figure 11: Whole rock and Ni composition diagrams for studied pyroxenites, and various lithologies that compose oceanic crust (MORBs = 'volcanic', and the deep plutonic crust 1225 'plutonic'). In all the diagrams, it is clear that the studied pyroxenites differ from oceanic crust 1226 lithologies. Also the Ni covariation with $\mathrm{MgO}$ highlights the compatible behavior of Ni during MORB differentiation ( $\mathrm{Ni}$ decreasing with $\mathrm{MgO}$ ), and shows that the studied pyroxenites contains higher amounts of Ni than any MORBs or even of the cumulative rocks from oceanic crust. Oceanic crust lithologies are presented using density graphs with MORB database 1230 provided by M. O’Hara (n=277), and plutonic rocks database taken from IODP Site U1309 1231 (Godard et al., 2009; n=173).

1232

1233 Figure 12: P-T-t paths for the studied pyroxenites. Phase diagram for the ultramafic system is 1234 constructed after Gasparik (2014) and references therein. With increasing pressure, 1235 encountered domains are: the plagioclase Iherzolites facies (A); the Seiland (B), and Ariegites 1236 (C) sub-facies that correspond to sub-divisions of the spinel lherzolites facies $(\mathrm{B}+\mathrm{C})$; and the 1237 garnet lherzolite facies (D). Reactions separating different facies when pressure increases are 1238 (1): $\mathrm{Pl}+\mathrm{Ol} \Leftrightarrow \mathrm{Cpx}+\mathrm{Opx}+\mathrm{Spl}$ between $\mathrm{A}$ and B (e.g., Takazawa et al., 1996); (2): 1239 $\mathrm{Opx}+\mathrm{Spl}+\mathrm{Pl} \Leftrightarrow \mathrm{Cpx}+\mathrm{Grt} \quad$ between $\mathrm{B}$ and $\mathrm{C} \quad$ (e.g., O’Hara, 1967); and (3): 
$1240 \mathrm{Cpx}+\mathrm{Opx}+\mathrm{Spl} \Leftrightarrow \mathrm{Ol}+\mathrm{Grt}$ between $\mathrm{C}$ and D (e.g., Johnson et al., 1990). The black line (4) is the

1241 "sapphirine reaction", namely $\mathrm{Opx}+\mathrm{Pl}+\mathrm{Spl} \Leftrightarrow \mathrm{Spr}+\mathrm{Grt}$; it occurs only at high temperature and 1242 at slightly higher pressure than reaction (2). $\mathrm{S}$ is solidus. The TAK-4 path needs further 1243 constraint, the early $\mathrm{P}$ drop is poorly documented and a pure cooling stage is possible for this 1244 sample (dotted line).

1246 Figure 13: Schematic evolution of the petrographic assemblage (a), and qualitative evolution 1247 of the major element (b), and trace element (c) whole rock compositions of the studied mantle 1248 cumulates. The crystallization stage corresponds to the Stage 2 in Figure 14, the 1249 metamorphism stage corresponds to the Stage 3 in Figure 14, and the metasomatism 1250 corresponds to the Stage 3' in Figure 14. In a) the initial cumulative assemblage (or magmatic 1251 assemblage from stage 2, marked 'I' in caption), is recrystallized during the subsolidus evolution (P-T-t variations) to a re-equilibrated metamorphic assemblage (marked 'II' in caption; Stage 3). Numbered circles represent the possible sampling of the cumulate by a given xenolith (theoretical samples 1-5). Xenolith ' 1 ' only samples Grt, xenolith 2 only 1255 samples Cpx, xenolith 3 only samples Opx, xenolith 4 samples a polymineralic assemblage of 1256 Cpx-Opx-Grt, xenolith 5 samples a polymineralic assemblage of Cpx-Grt. Similar sampling areas are highlighted at Stage 3 when those initial cumulative assemblages have recrystallized 1258 to metamorphic assemblages. b) and c) highlight that no modification of the whole rock 1259 composition is expected during the subsolidus evolution. Only metasomatism (Stage 3') can 1260 modify mainly the geochemical composition (enrichment in LREE and some other elements, 1261 see Section 8.3 and Table 1). In our theoretical evolution all the samples, but xenolith 3, have 1262 suffered metasomatic interactions. REE elements evolution is only qualitative, and based on 1263 minerals' Kds, and on the consideration that metasomatism is associated to LREE enrichment. 
1265 Figure 14: General schematic evolutionary model for the studied pyroxenites. At stage 1, an

1266 orogen is formed. At stage 2, the exhumation triggers a sub-isotherm decompression in the mantle, resulting in partial melting; the formed melt percolates the mantle section, and crystallizes the studied pyroxenites. After stage 2, studied pyroxenites are crystallized and their subsequent P-T-t evolution can be followed on Figure 12; their petrographical and

1270 geochemical evolution can be followed on Figure 13. Between stage 2 and 3, the exhumation 1271 is continuous until a thermal re-equilibration. After stage 3 the lithosphere is in a thermal classical regime, and contains heterogeneities (i.e., the studied pyroxenites), at that stage mantle domains can suffer metasomatism reactions (=stage 3'). Stage 4: the subsequent lithospheric evolution (thermal anomaly or rifting initiation), and with modified physical 1275 properties. In particular, the presence of pyroxenite cumulates lowers the global solidus. 1276 Compared to lherzolitic mantle regions ('un-refertilized lherzolite mantle'), partial melts will therefore occur earlier (at lower temperature), and melt production will be higher for a given temperature in such refertilized areas ('refertilized mantle').

1280 Table 1: Sample list, region, locality, rock type, modal composition, primary magmatic 1281 paragenesis, primary magmatic facies, subsolidus paragenesis and features, facies transitions, 1282 metasomatic paragenesis or features, late features and alteration phases, microtextures, 1283 average grain size, and estimated temperatures for the studied pyroxenites. Modal proportions 1284 are given in \%, $t$ indicates amounts as traces. FMC stands for French Massif Central.

1286 Table 2: Major element composition of minerals (in wt \%). Same abbreviations as in Table 1. $1287 n$ is the number of analyses that is averaged. In the comment column, $O p x 1$ and $P l 1$ indicate 1288 minerals observed as inclusions in Grt; reactional indicates minerals observed in the fine1289 grained Opx-Pl-Spl assemblages in FMC samples (Figure 2d). Data for Le Pouget sample are 
1290 from Fabriès et al. (1987). \% Ph is the An content for $\mathrm{Pl}$, the \#Cr for Spl, and the \#Mg for

1291 other phases (molar basis); \% $\mathrm{Ph} 2$ is the jadeite content for Px, the pyrope content for Grt, and 1292 the K-feldspar content for Pl.

1293

1294 Table 3: Trace element concentration for minerals (ppm). Same abbreviations as in Table 1. $n$ 1295 is the number of analyses that is averaged. ' and " on sample names indicates that different 1296 types of minerals are present. Underlined minerals have been analyzed at the IGG (Pavia), 1297 others at LMV (Clermont-Ferrand).

1298

1299 Table 4: Major (wt \%) and trace (ppm) element whole rock compositions. $L N-78 a$ and $L N$ $130078 b$ represent two different domains of sample LN-78, and $L N-78$ - $a v g$ the averaged value. $b d l$ 1301 means below detection limit.

1302

1303 Table 5: Isotopic composition of mineral separates. Same abbreviations as in Table 1. For 1304 oxygen isotope composition, some samples have been duplicated. std err is the standard error 1305 on the measurement. 


\section{Supplementary material:}

\section{Figure S1:}

1309 a) Oxygen isotope fractionation between Grt and $\mathrm{Cpx}$. For reference, the $\Delta^{18} \mathrm{O}=0$ line is 1310 shown (continuous line). The dashed line corresponds to fractionation at $900^{\circ} \mathrm{C}$ calculated 1311 using the fractionation factors of Zheng (1993). b) Oxygen isotope fractionation between Opx 1312 and Cpx. For reference, is shown the $\Delta^{18} \mathrm{O}=0$ line (continuous line), and the field for

1313 lherzolites from Yemen (Chazot et al., 1997). Cpx and Grt oxygen isotopic compositions are 1314 positively correlated and plot below the line corresponding to $\Delta_{\mathrm{Cpx}-\mathrm{Grt}}=-0.4 \%$, indicating that 1315 these minerals have been equilibrated to $\mathrm{T}$ above $900^{\circ} \mathrm{C}$, in agreement with $\mathrm{T}$ calculated 1316 using their chemical composition (see section 8.1.2.). Three samples from Cameroon (YK-01, 1317 YK-03, and YK-05) have positive $\Delta_{\text {Cpx-Grt }}$ values and record slight O-isotope disequilibrium. $1318 \Delta_{\text {Cpx-Opx }}$ values are negative for all but two samples; the values are heterogeneous but always 1319 above $\Delta_{\mathrm{Cpx}-\mathrm{Opx}}=-0.8 \%$.

1321 Table S1:

1322 Redox calculations results.

\section{Analytical techniques}

1325 This study is based on analyses of whole rocks, and minerals that have been separated under 1326 binocular microscope for their purity after crushing, sieving and washing. In-situ analyses 1327 have been made on polished thin sections $(30,100$ or $150 \mu \mathrm{m}$ thick).

1328 Major element mineral compositions were determined using the Cameca SX100 electron 1329 microprobe at the "Laboratoire Magmas et Volcans" (LMV) of Université Blaise-Pascal,

1330 Clermont-Ferrand, France. Instrument calibration was performed on natural standards and 1331 operating conditions were $15 \mathrm{kV}$ accelerating potential, $15 \mathrm{nA}$ beam current and $15 \mathrm{~s}$ counting 
1332 time on peak and background. Backscattered electron (BSE) images and EDX X-ray maps

1333 were obtained on the scanning electron microscope at LMV. The modal compositions of

1334 Cameroon samples have been computed from $\mathrm{Al}, \mathrm{Mg}, \mathrm{Ca}, \mathrm{Fe}$ mapping with the MultiSpec

1335 software (CPurdue Research $\quad$ Foundation, Inc.

1336 http://dynamo.ecn.purdue.edu/ biehl/MultiSpec/).

1337 Trace element mineral compositions have been determined using a LA-ICP-MS at LMV and

1338 at the CNR-IGG of Pavia. At Pavia the LA-ICP-MS instrument couples a double focusing

1339 sector field ICP mass spectrometer (Element IR from Thermo-Finnigan) with a Q-switched

1340 Nd:YAG laser source (Quantel Brilliant) operating at $213 \mathrm{~nm}$. The laser was operated at a

1341 repetition rate of $10 \mathrm{~Hz}$, and the spot diameter was varied from 20 to $40 \mu \mathrm{m}$ with a pulse

1342 energy in the range 0.01-0.03 mJ. Helium was used as the carrier gas and was mixed with Ar

1343 downstream of the ablation cell. Quantification has been done using the NIST SRM 612 glass

1344 as external standard, with 44Ca as internal standard. Precision and accuracy were assessed on

1345 the USGS BCR-2(g) reference glass and are both better than $10 \%$ for concentration at ppm

1346 level. At LMV, a Q-switched Nd-YAG laser source operating at $266 \mathrm{~nm}$ was coupled with a

1347 PQ2+ ICP-MS from Fisons. The laser was operated at a repetition rate of $10 \mathrm{~Hz}$ and the spot

1348 diameter was around $60 \mu \mathrm{m}$. Other analytical parameters are identical to those at Pavia

1349 laboratory and the precision and accuracy achieved are at the same level.

1350 Whole rock major and trace element concentrations have been determined by a lithium

1351 metaborate fusion method and using an ICP-AES and an ICP-MS, respectively at the

1352 Activation Laboratories (Ontario). For sample from "Le Pouget" (FMC), the available sample

1353 amount was very small and the whole rock trace element content has been estimated using the

1354 mineral trace element compositions, and the modal proportions.

1355 The oxygen isotopic composition of mineral separates was analyzed at the CNR-IGG of Pisa

1356 (Italy), by conventional laser fluorination, reacting the samples under a $F_{2}$ gas atmosphere. 
1357 For each sample, 1 to $2 \mathrm{mg}$ of separated grains were placed under a $25 \mathrm{~W}$ Merchantek $\mathrm{CO}_{2}$

1358 laser. The produced reaction triggers the oxidation of the different mineral molecules, and

1359 liberates the $\mathrm{O}_{2}$ following reactions as $2 \mathrm{MgO}+\mathrm{SiO}_{2}+\mathrm{xF}_{2} \Leftrightarrow 2 \mathrm{MgF}_{2}+\mathrm{SiF}_{4}+2 \mathrm{O}_{2}+(\mathrm{x}-4) \mathrm{F}_{2}$ (with a

1360 large $\mathrm{x}$ in order to achieve a high total yield). The gas mixture was injected in a separation line

1361 in which different cold trap and heated salts $\left(\mathrm{KCl}\right.$ at $\left.\sim 140^{\circ} \mathrm{C}\right)$ allow us to trap all the

1362 molecules but $\mathrm{O}_{2}$. The purified $\mathrm{O}_{2}$ is thereafter injected in a mass spectrometer (Finnigan

1363 MAT Delta plus XP) to analyze the different isotopes. A laboratory inner reference gas is

1364 jointly analyzed to compare the analyzed sample with the V-SMOW international standard.

1365 The $\delta^{18} \mathrm{O}$ value is then calculated (with $\delta^{18} \mathrm{O} \% \mathrm{o}=\frac{{ }^{18} \mathrm{O}^{16} \mathrm{O}_{(\text {sample })}}{{ }^{18} \mathrm{O} /{ }^{16} \mathrm{O}_{(\mathrm{V}-\mathrm{SMOW})}} \quad 1 \quad 1000$ ). The

1366 average reproducibility of oxygen isotope analyses of silicate minerals is $0.16 \%$. Standards

1367 were analyzed at the beginning and end of each analytical series; these were the in-house

1368 laboratory standard QMS quartz (theoretical $\delta^{18} \mathrm{O}$ value $=14.05 \%$ ), and UWG-2 garnet

1369 (theoretical $\delta^{18} \mathrm{O}$ value $=5.8 \%$ ).

1370 The Sr-Nd radiogenic isotopic analyses have been achieved at LMV using a thermo ionization

1371 mass spectrometer (TIMS) Triton from Thermo-Finnigan. Each analysis has been

1372 accomplished on $100 \mathrm{mg}$ of separate $\mathrm{Cpx}$. Sr and $\mathrm{Nd}$ were extracted following a

1373 chromatographic extraction method after having effectuated a leaching: $30 \mathrm{~min}$ in $\mathrm{HCl} 2.5 \mathrm{~N}$,

$137415 \mathrm{~min}$ in $\mathrm{HF} 5 \%, 30 \mathrm{~min}$ in $\mathrm{HCl} 2.5 \mathrm{~N}$ and $30 \mathrm{~min}$ in distilled water. Samples were then

1375 evaporated on tungsten filaments and analyzed using the double filament method with the

1376 TIMS Finnigan Triton. Standards used for this study are BIR-1 $0.703136 \pm 4$ and NBS987

$1377 \quad 0.710279 \pm 4$ for Sr and BIR-1 0.513111 \pm 4 and AMES $0.511960 \pm 3$ for Nd. 
Stage 1 -Orogen $\quad$ Stage 2 - Late orogenic exhumation

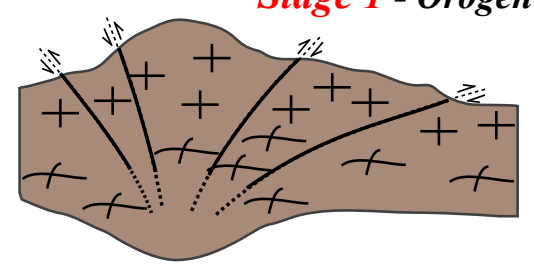

Mantle
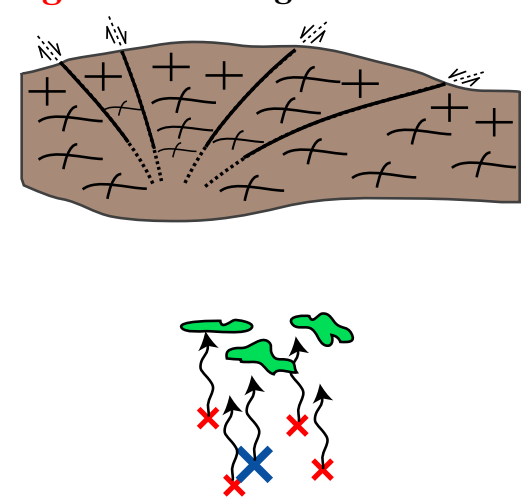

Stage 3 - Continuing exhumation and $P$-T reequilibration

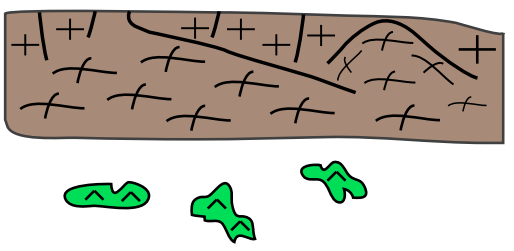

Refertilized mantle (high concentration of pyroxenites)

Stage 4

Post orogenic initiation of thermal anomaly or mantle plume

\section{POST OROGENIC CYCLE}

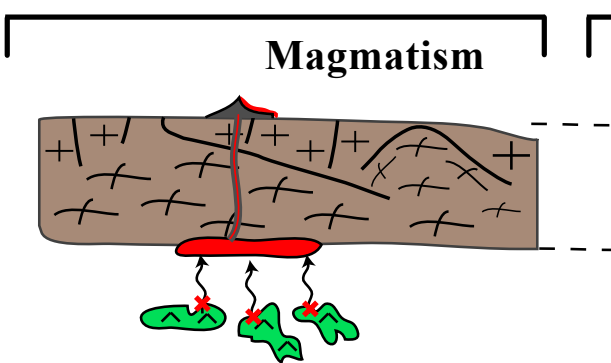

Refertilized mantle

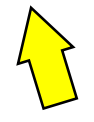

\section{NO FORMER OROGENIC CYCLE}

No magmatism

Initiation of thermal anomaly

$+\quad$ Upper crust

+ Lower crust

* Pyroxenites mantle source

$\times \quad$ Mantle partial melting

$\uparrow$ Melt migration

$\approx$ Pyroxenites crystallization

A Studied pyroxenites
Un-refertilized

lherzolite mantle

$\Delta^{\text {(no pyroxenite) }}$ 

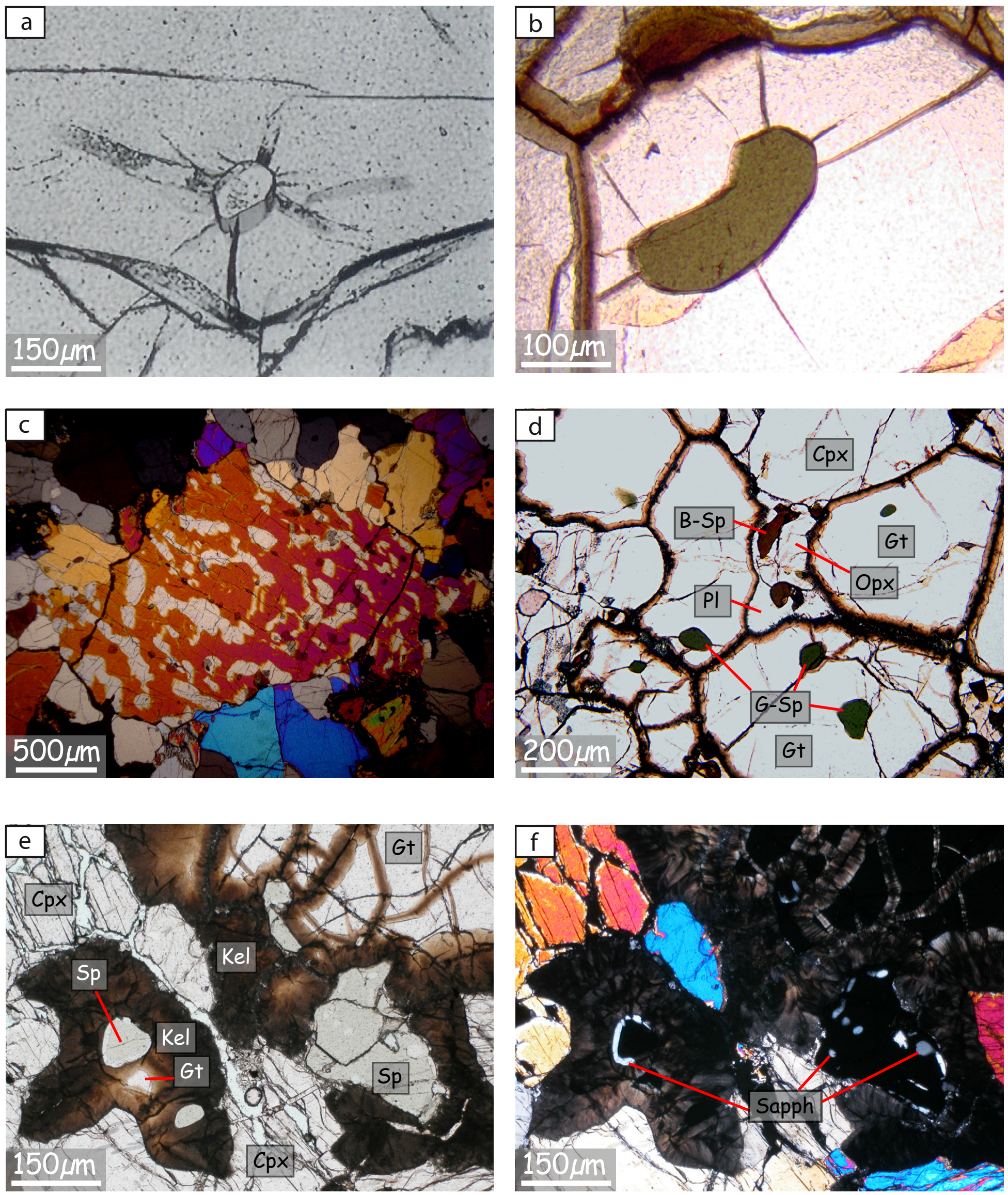

France et al., Fig. 2 



France et al., Fig. 2; continuous 

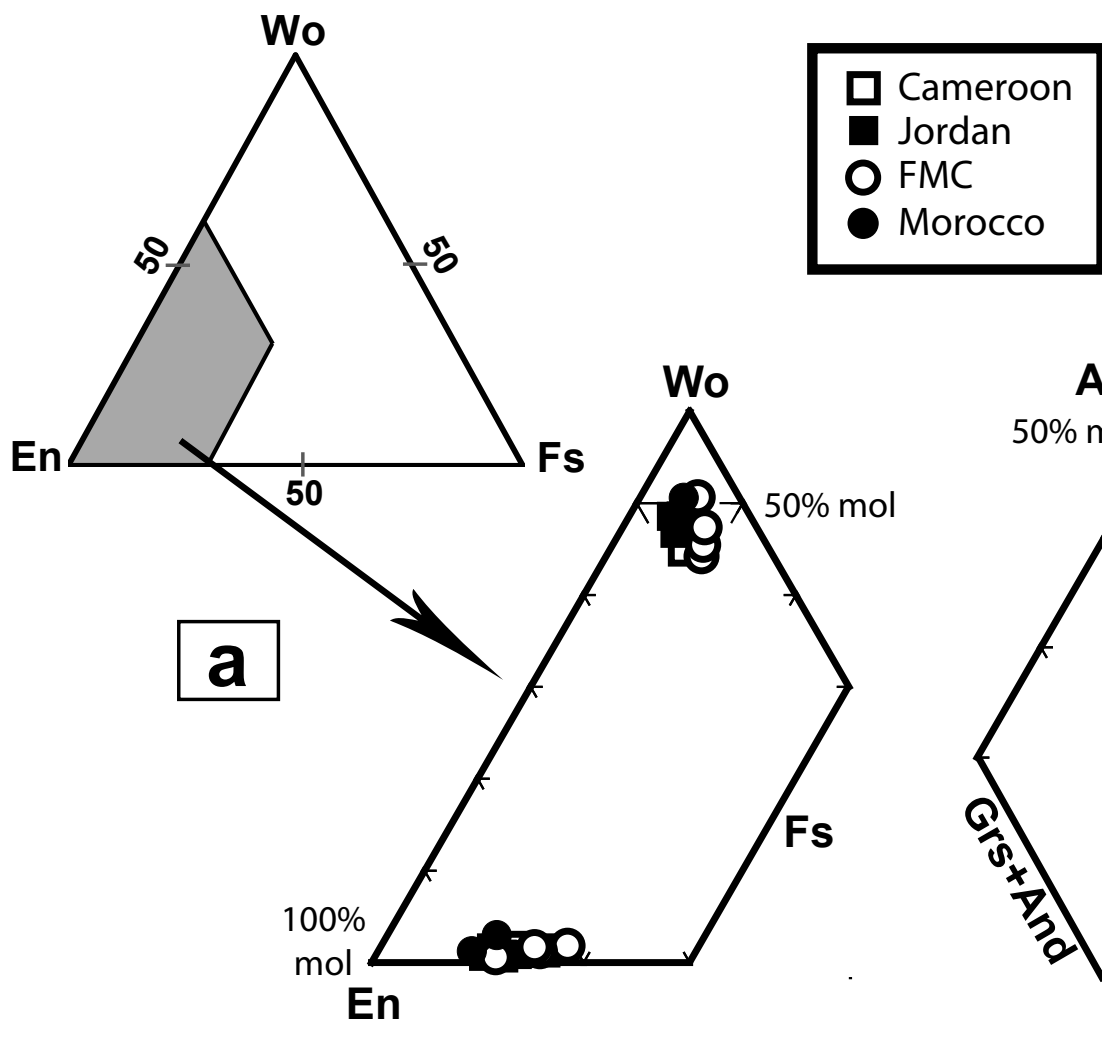

Alm+Spess

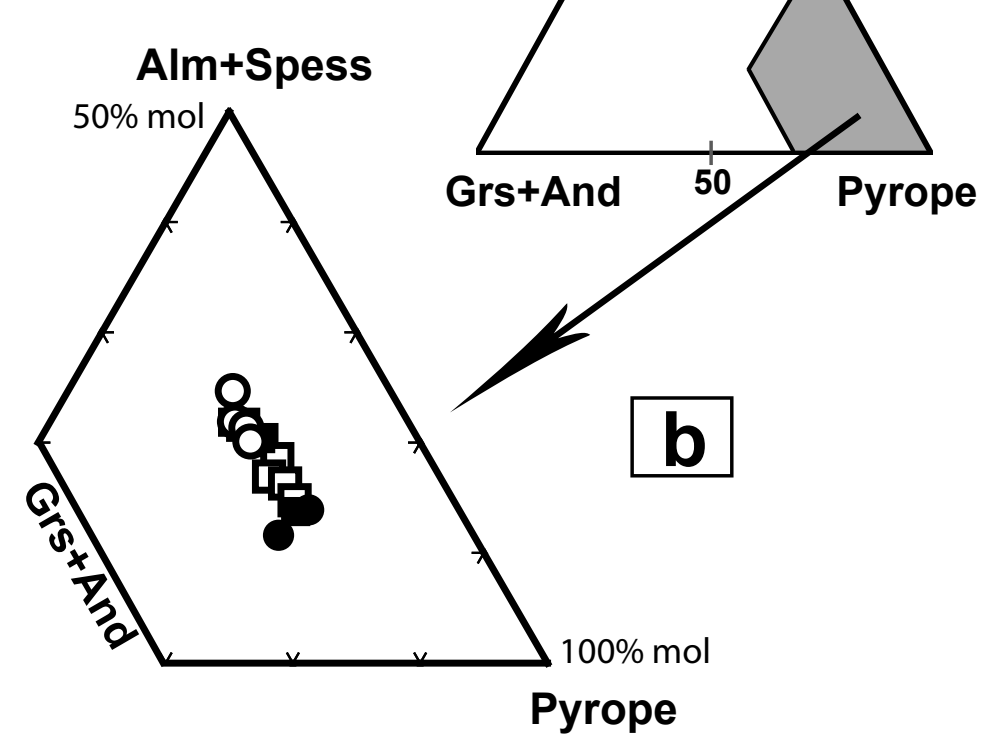

France et al., Fig. 3 


\begin{tabular}{|c|c|c|c|c|}
\hline FMC & Morocco & \multicolumn{2}{|c|}{ Cameroon } & Jordan \\
\hline$\times$ LN-78 & & Y YYK-01 & * YK-12 & $\square$ Jo-7b \\
\hline$+\mathrm{LP}-27$ & $\triangle$ TAK-3 & - YK-03 & $\begin{array}{l}\text { * YK-1L } \\
\text { O YK-13 }\end{array}$ & Jo-7h \\
\hline $\begin{array}{l}\text { is SD-53 } \\
\text { Le Pouget }\end{array}$ & $\Delta$ TAK-4 & + YK-05 & $\times$ YK-16 & $\begin{array}{ll}\diamond \mathrm{Jo}-10 \mathrm{e} \\
\mathrm{J}\end{array}$ \\
\hline
\end{tabular}
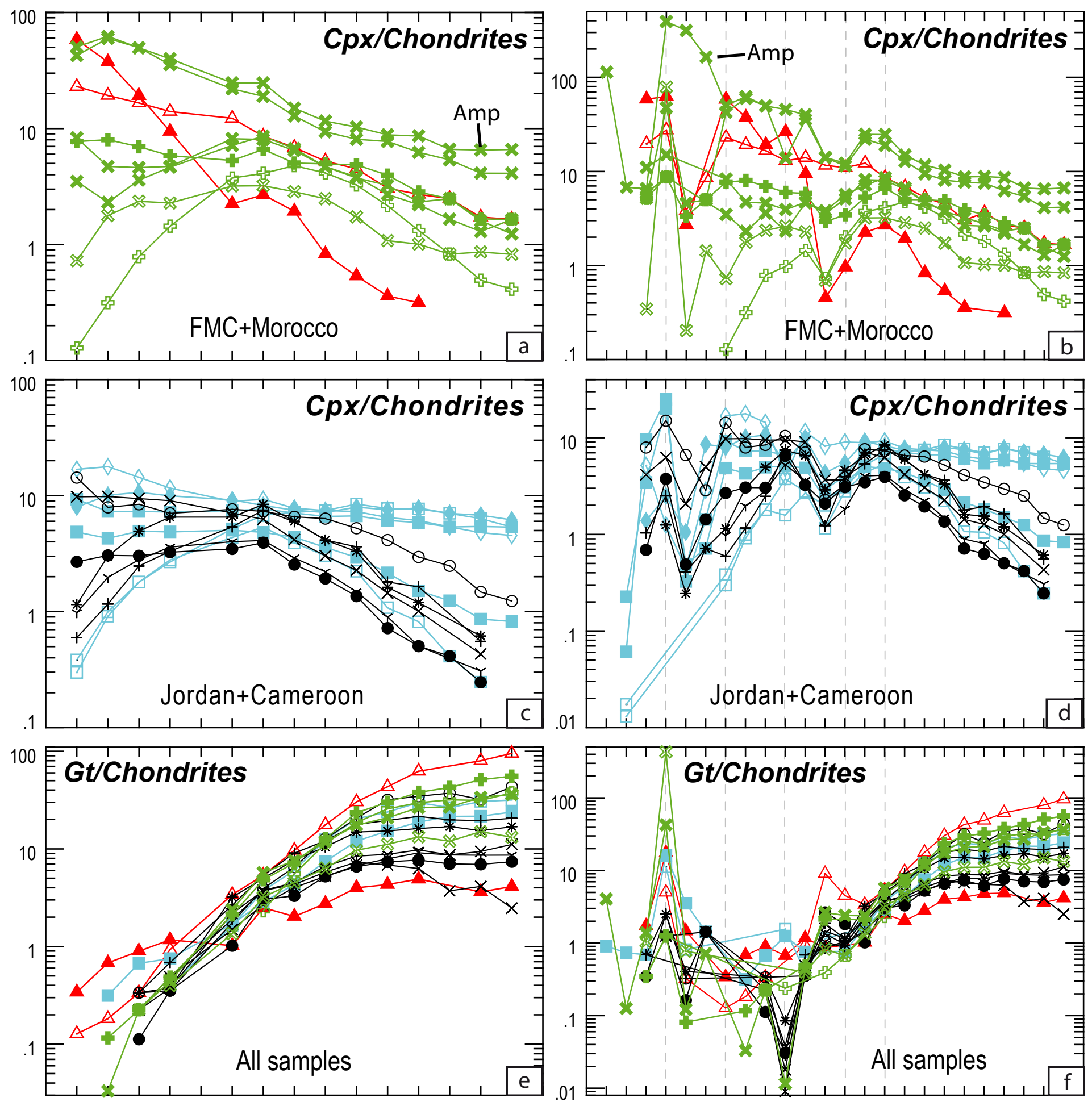

La Ce Pr Nd Pm Sm Eu Gd Tb Dy Ho Er Tm Yb Lu

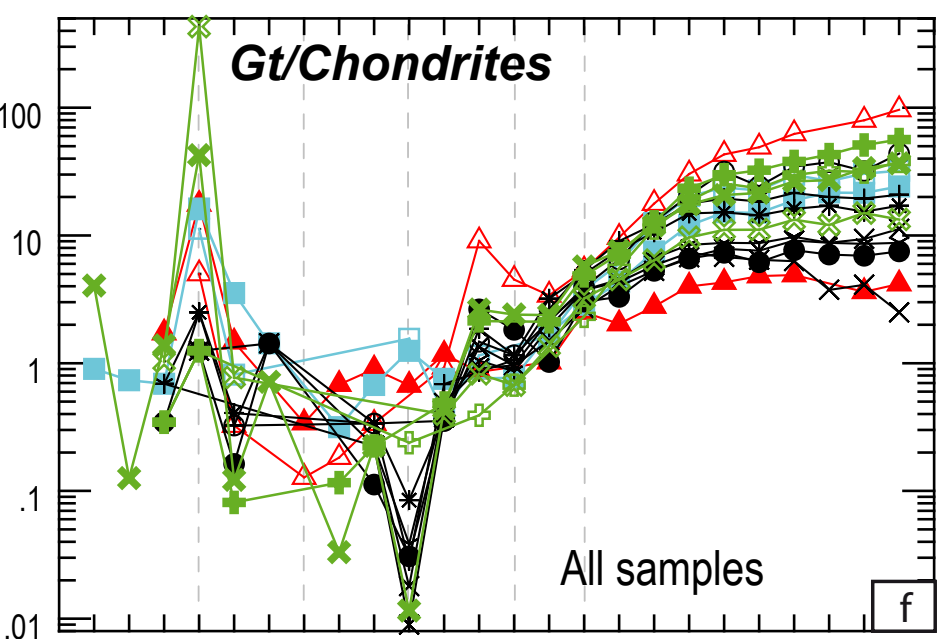

BaRbTh U NbTa LaCePr SrNd Zr HfSmEuGdTbDyHo Y ErTmYbLu

France et al., Fig. 4 

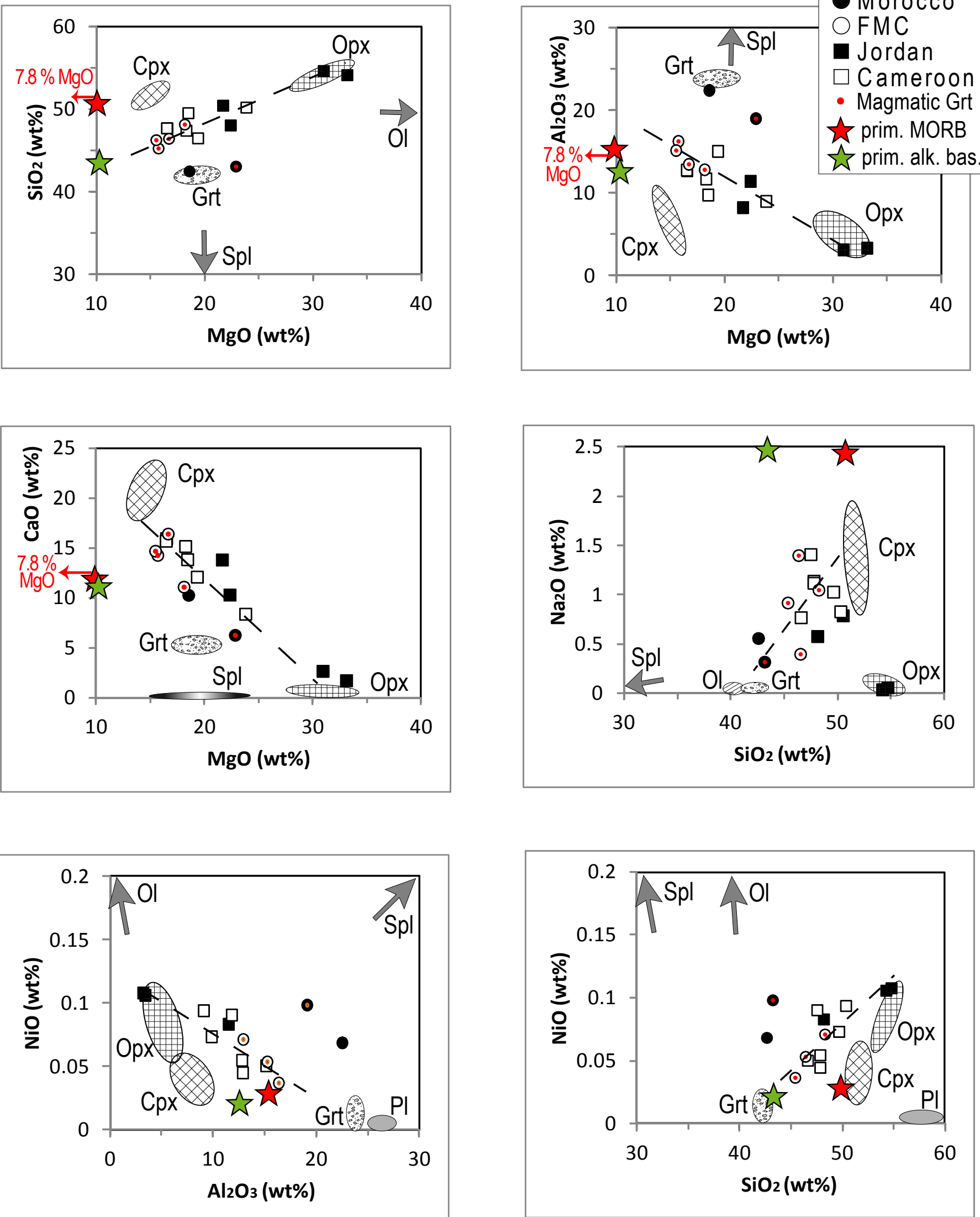

France et al., Fig. 5 


\begin{tabular}{|c|c|c|c|c|}
\hline FMC & Morocco & Cam & oon & Jordan \\
\hline $\begin{array}{l}\text { x LN-78 } \\
+ \text { LP-27 } \\
\text { « SD-53 } \\
\text { ↔ Le Pouget }\end{array}$ & $\begin{array}{l}\triangle \text { TAK-3 } \\
\triangle \text { TAK-4 }\end{array}$ & $\begin{array}{l}\text { Y YK-01 } \\
\text { - YK-03 } \\
+ \text { YK-05 }\end{array}$ & $\begin{array}{l}* \text { YK-12 } \\
\text { O YK-13 } \\
\times \text { YK-16 }\end{array}$ & $\begin{array}{l}\square \text { Jo-7b } \\
\square \text { Jo-7h } \\
\text { Jo-10e } \\
\text { Jo-12h }\end{array}$ \\
\hline
\end{tabular}
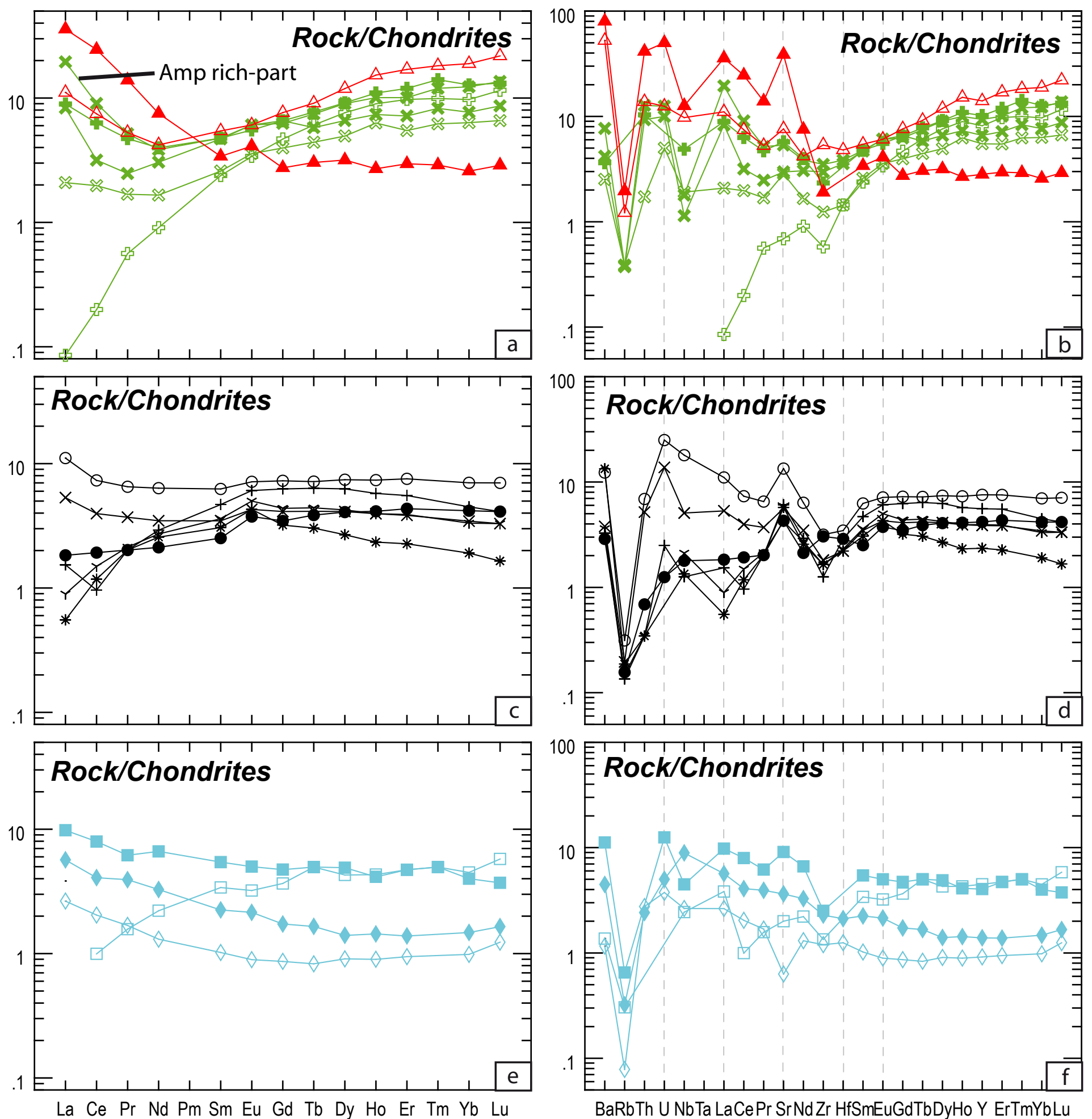

France et al., Fig. 6 

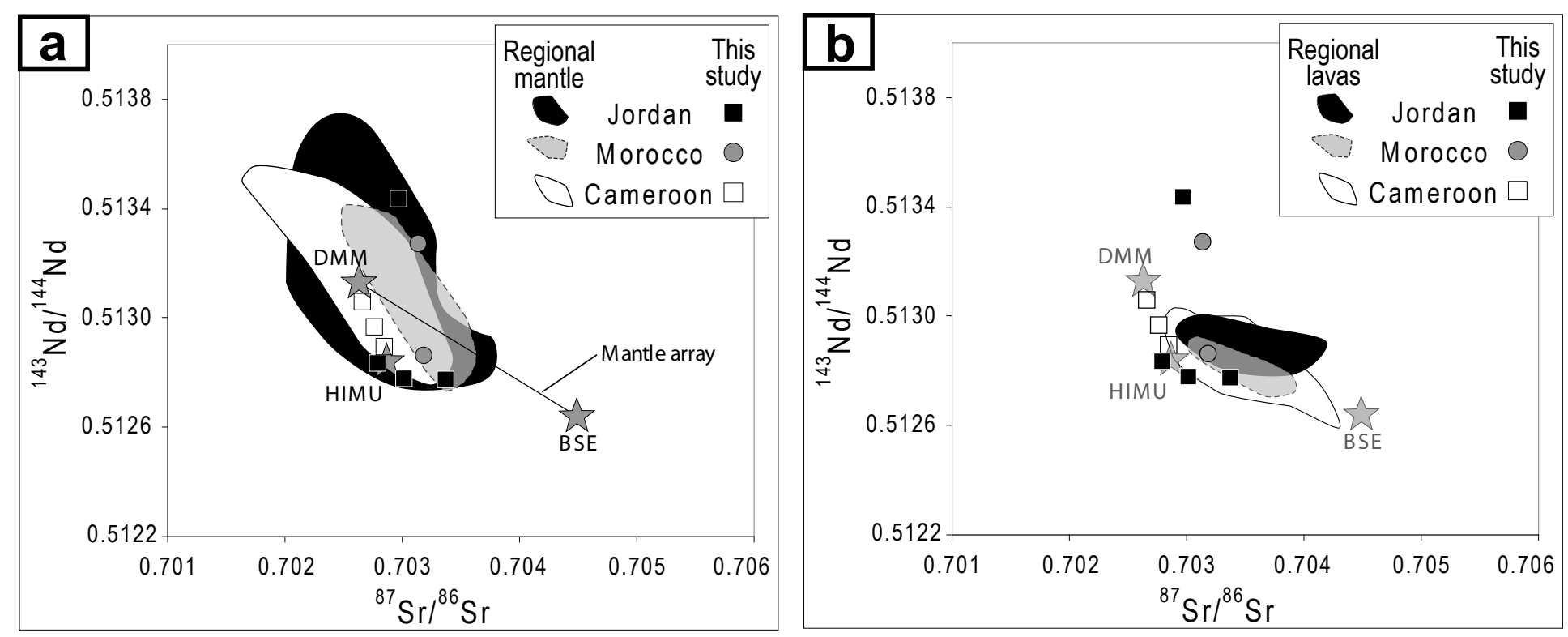

France et al., Fig. 7 


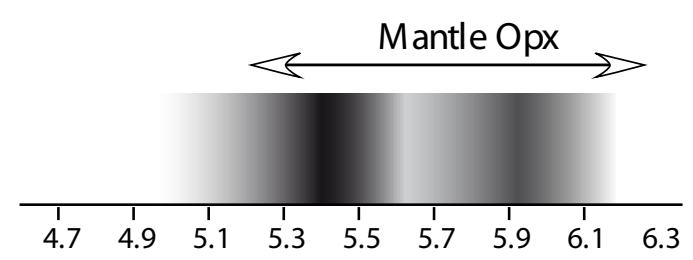

$\delta^{18} \mathrm{O}_{\text {Orthopyroxene }}(\%$ SMOW), $n=11$

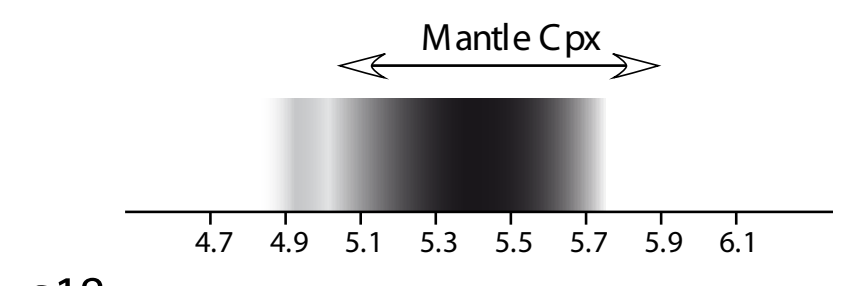

$\delta^{18} \mathrm{O}_{\text {Clinopyroxene }}$ (\%o SMOW), $n=18$

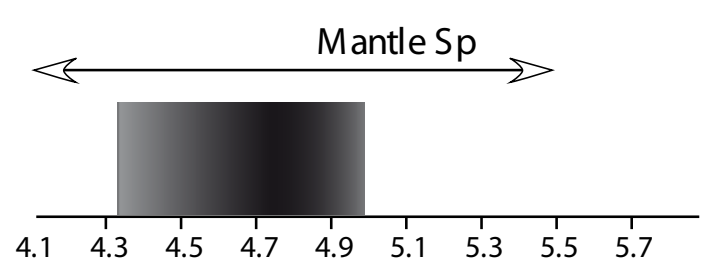

$\delta^{18} \mathrm{O}_{\text {Spinel }}(\%$ SMOW), $n=9$

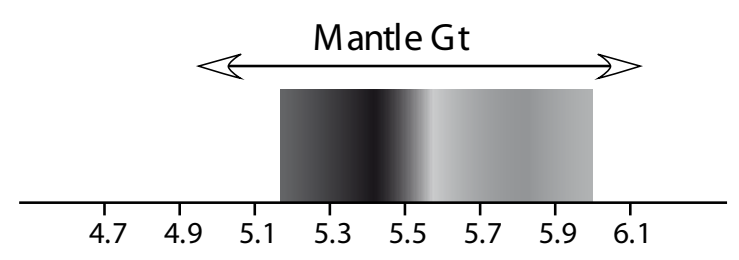

$\delta^{18} \mathrm{O}_{\text {Garnet }}(\% \circ \mathrm{SMOW}), n=12$

Recycled samples (eclogites) composition: from 2 to $10 \%$

France et al., Fig. 8 

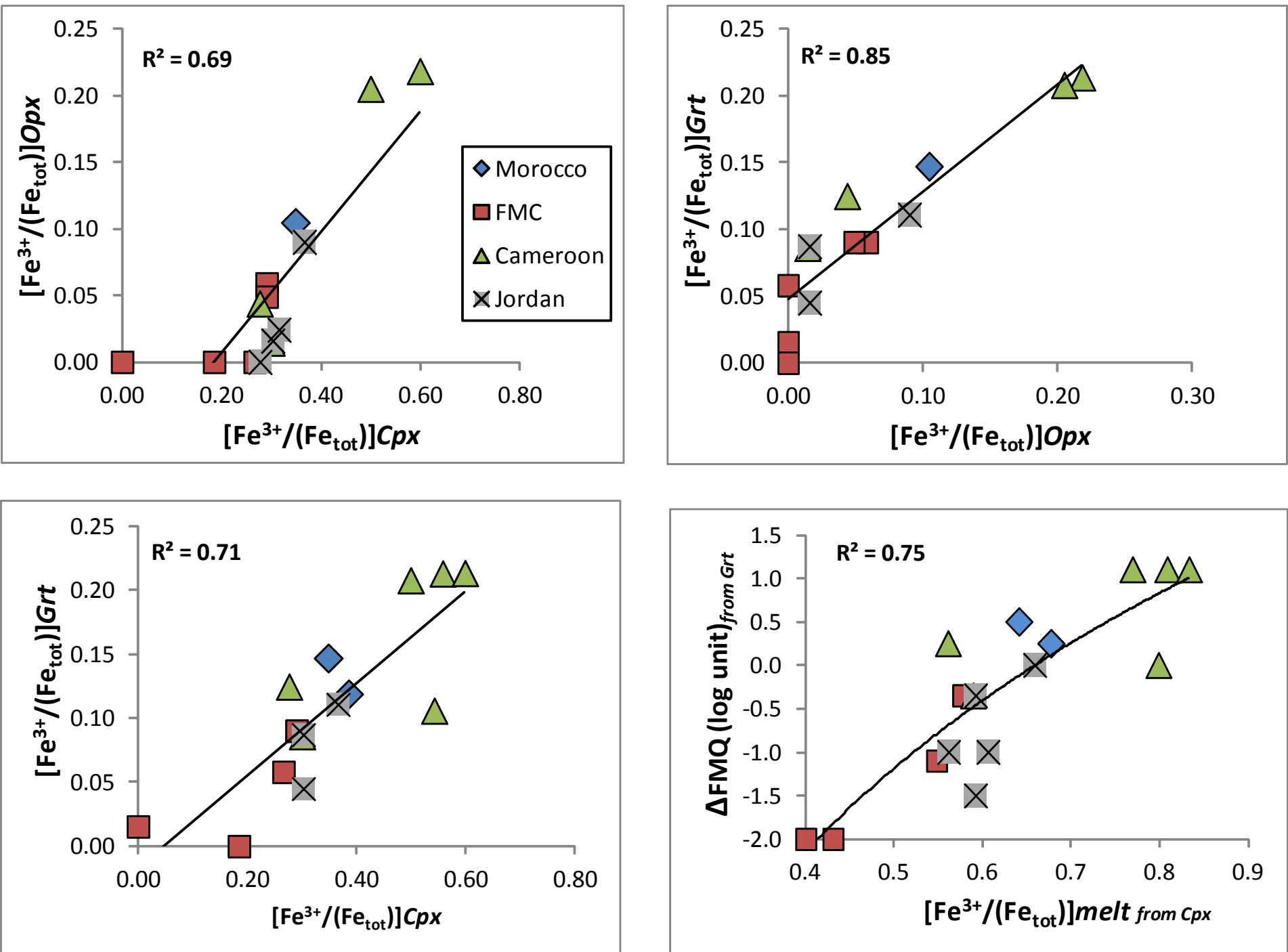

France et al., Figure 9 

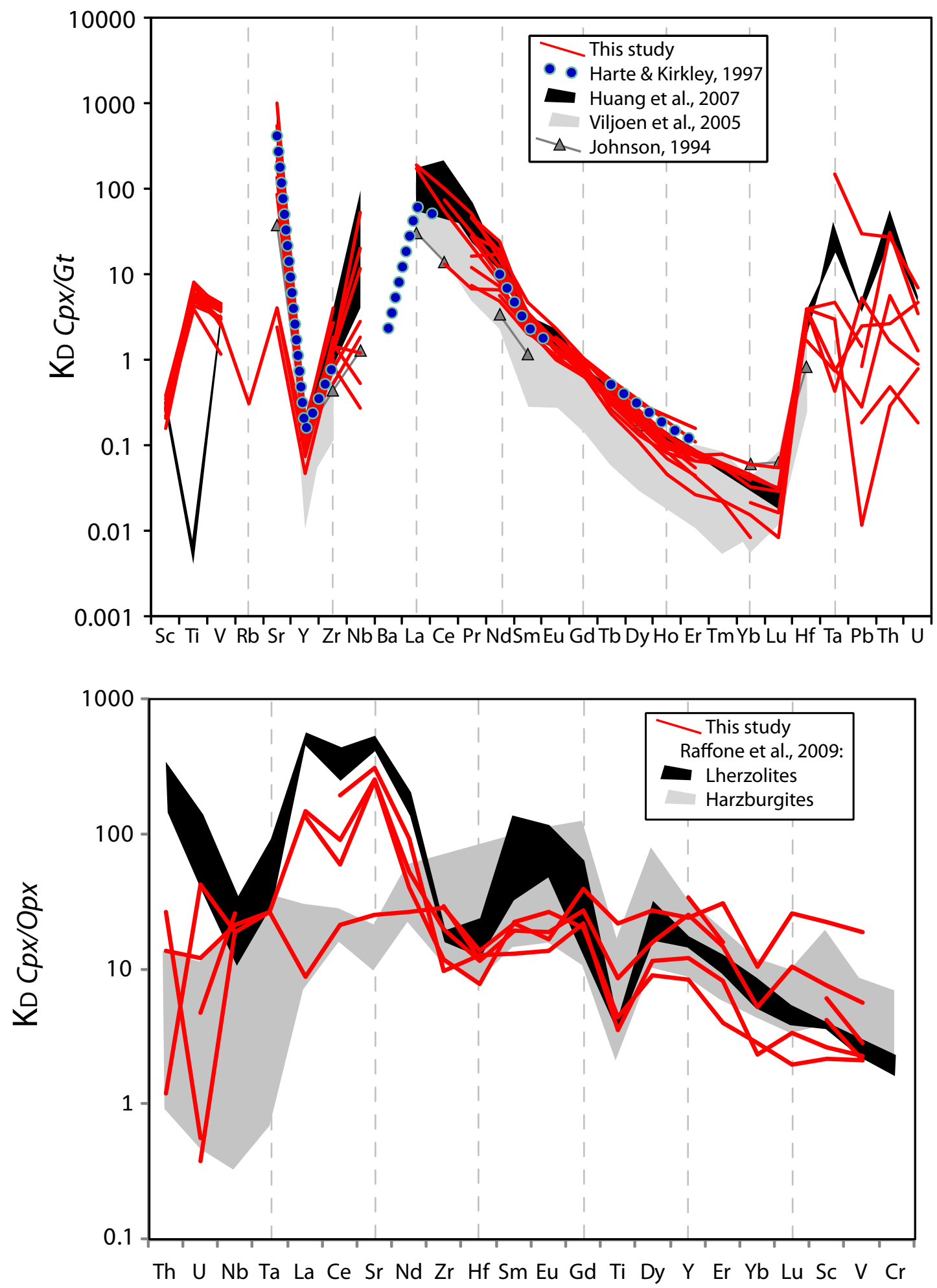

France et al., Fig. 10 


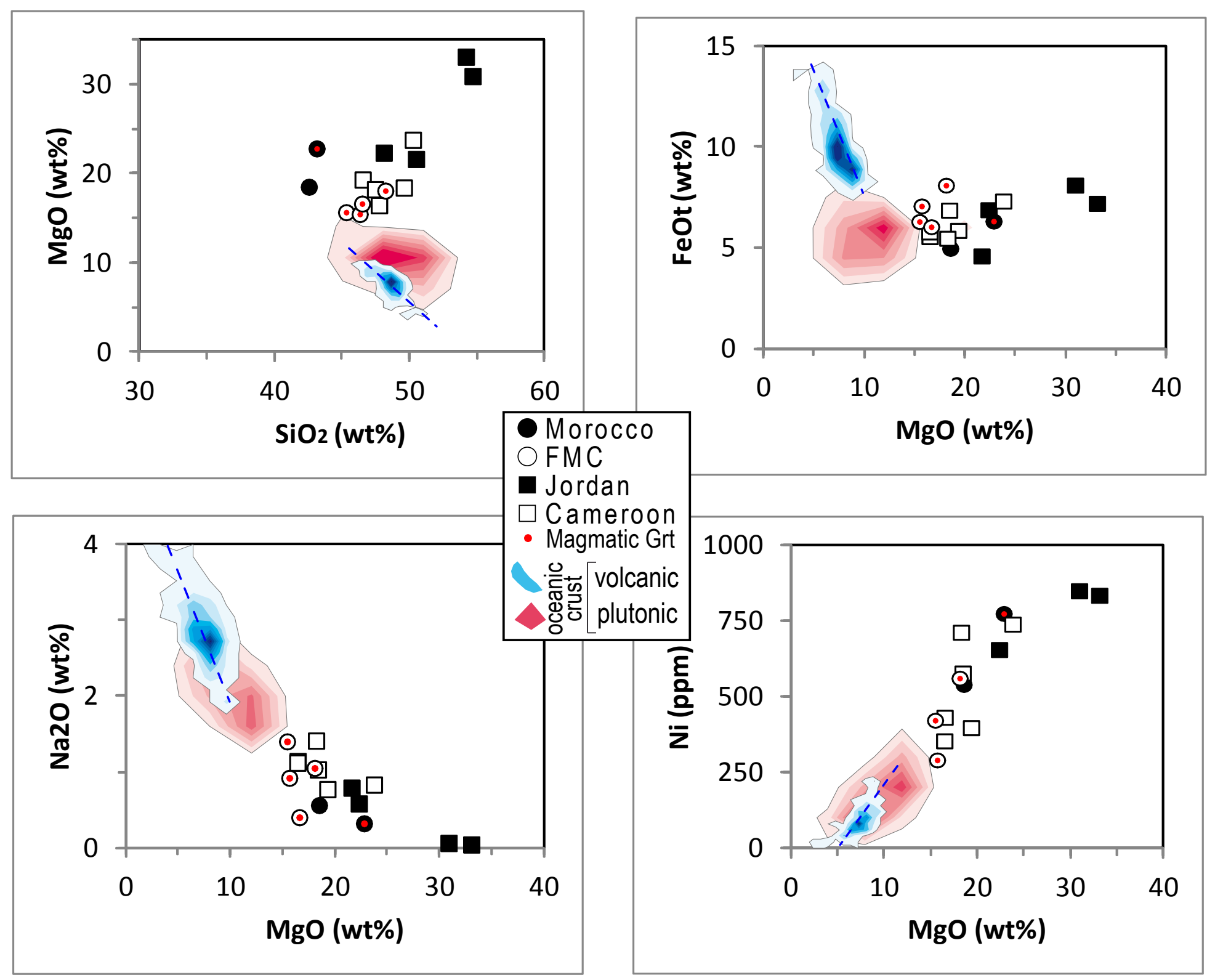

France et al., Fig. 11 


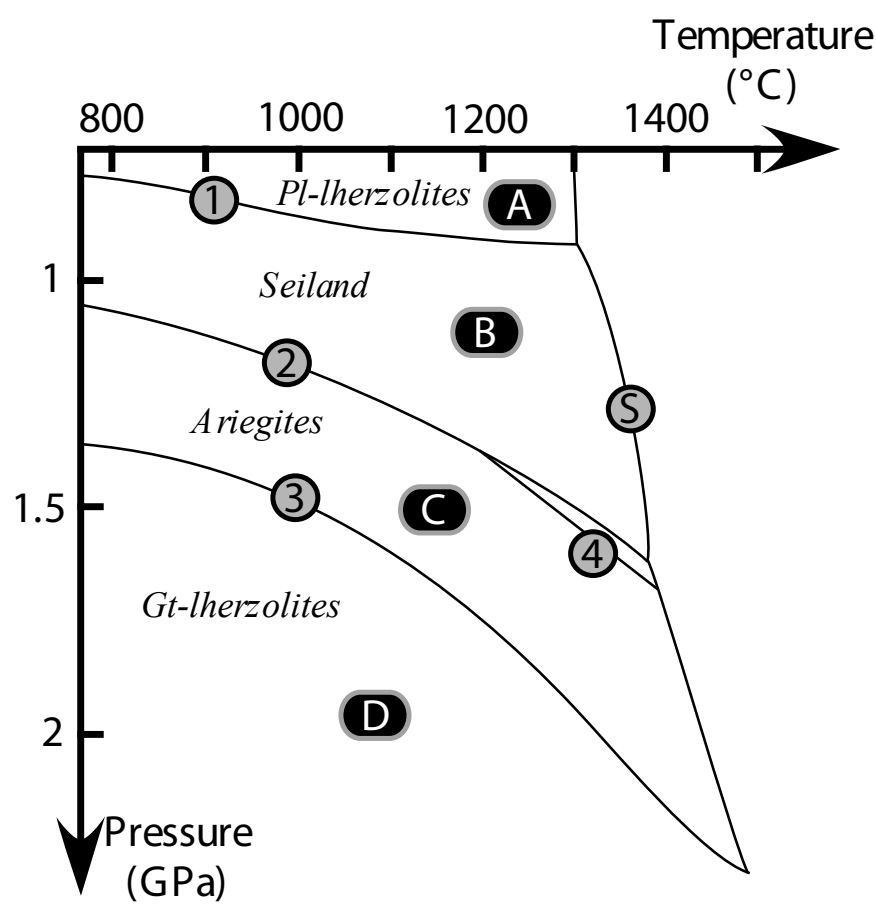

a)

Temperature

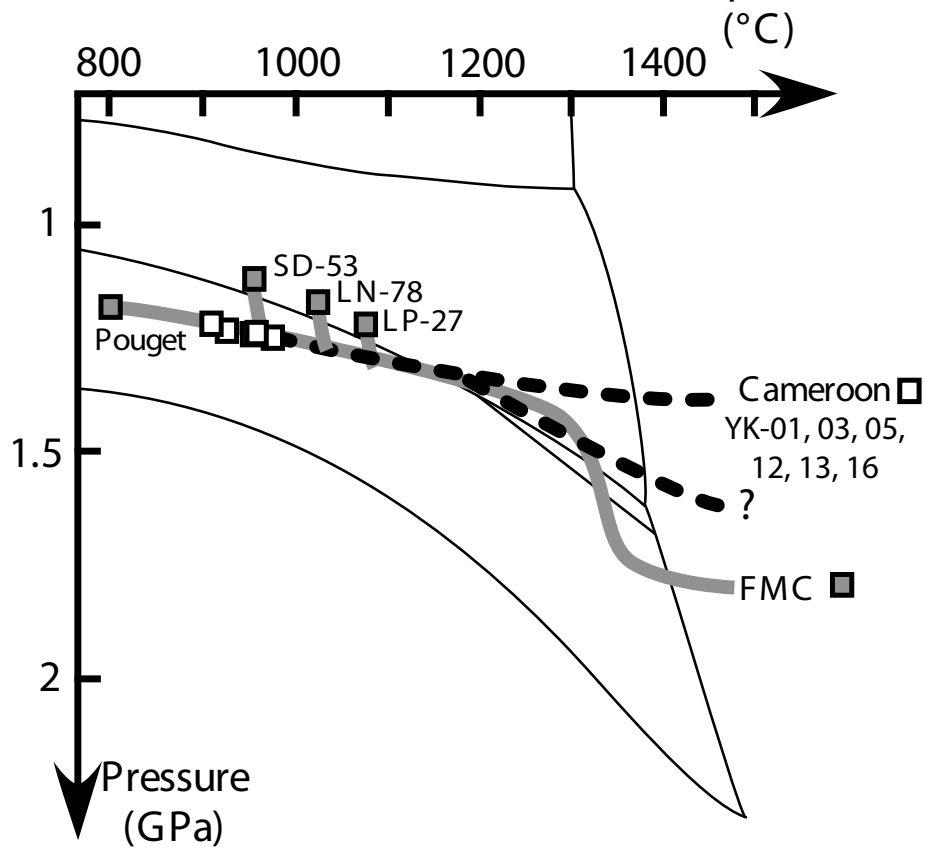

b)

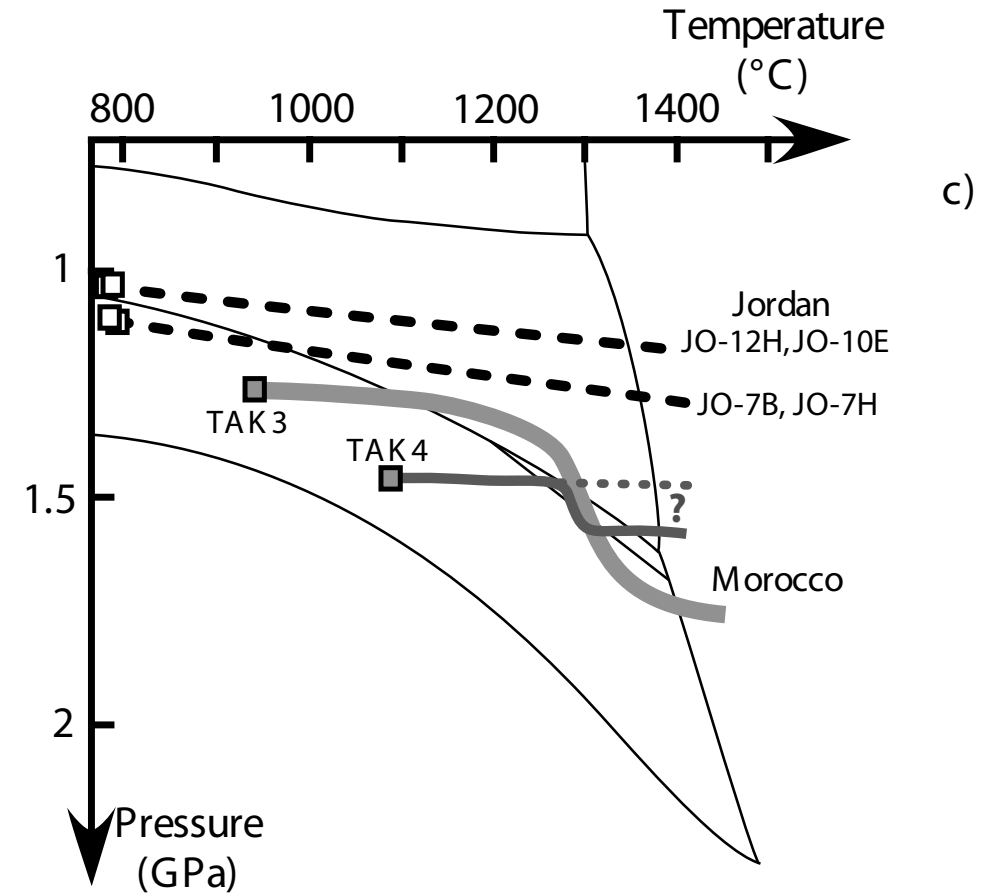

France et al., Fig. 12 
a crystallization stage (=stage 2 in Fig. 14)

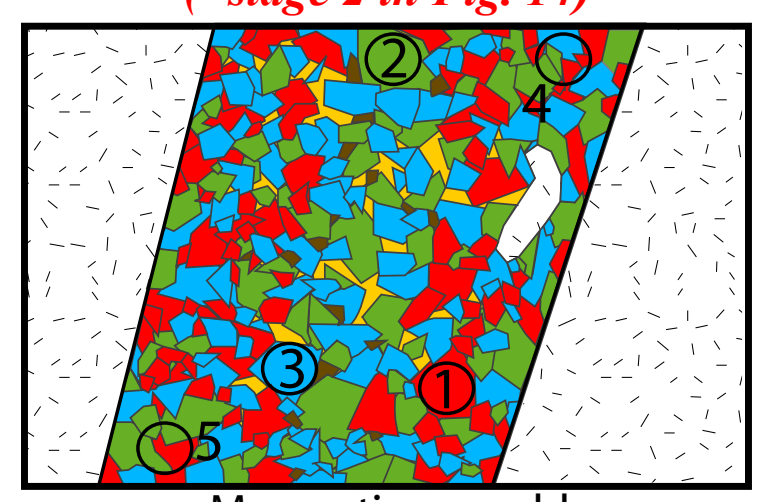

Magmatic assemblage metamorphism during PT evolution

[ $\quad$, host peridotite 1II orthopyroxene 111 clinopyroxene III garnet III spinel

II plagioclase

$\square$ interstitial melt

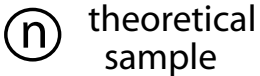
(=stage 3 in Fig. 14)

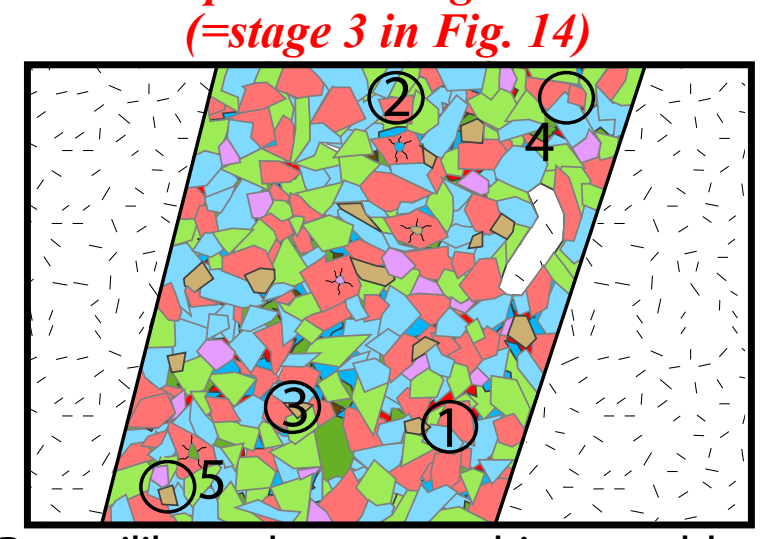

Reequilibrated metamorphic assemblage b

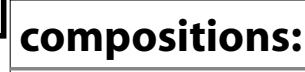

Whole rock:

theoretical sample names

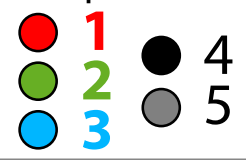

\section{Minerals:}

\#px Gt

$\otimes$ Cpx PI

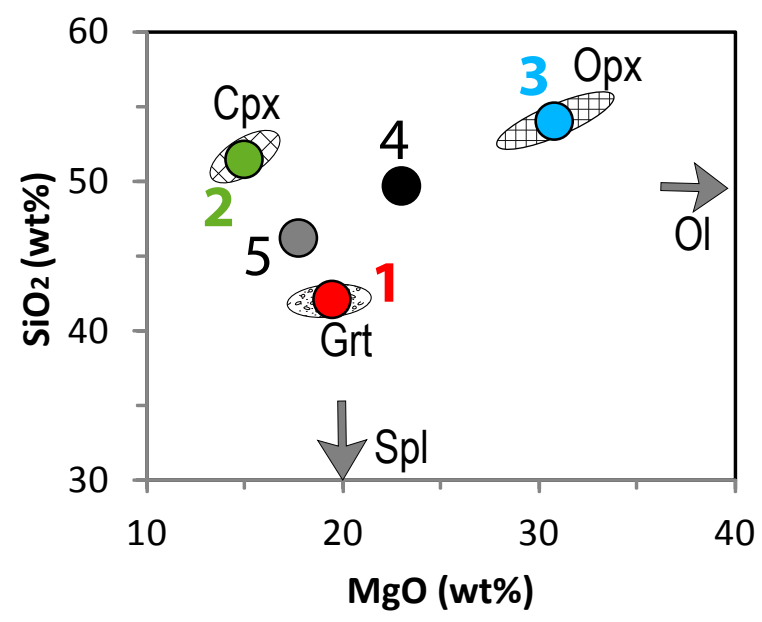

stage 2 = stage 3

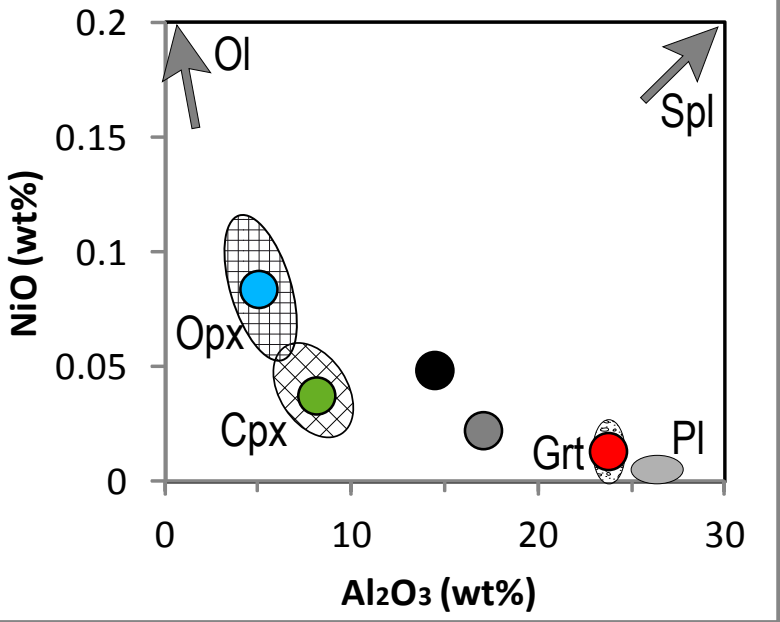

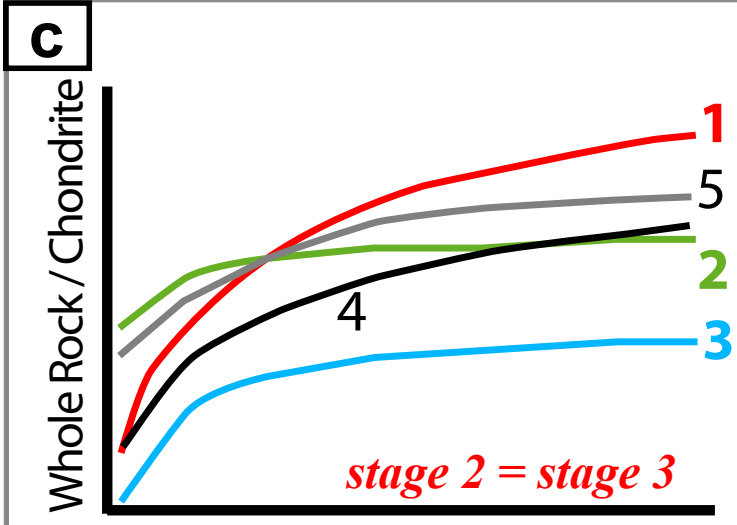

Rare Earth Elements

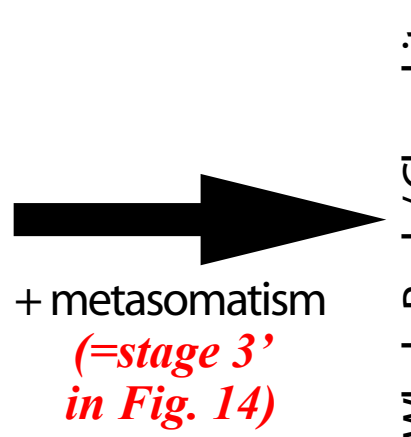

in Fig. 14)

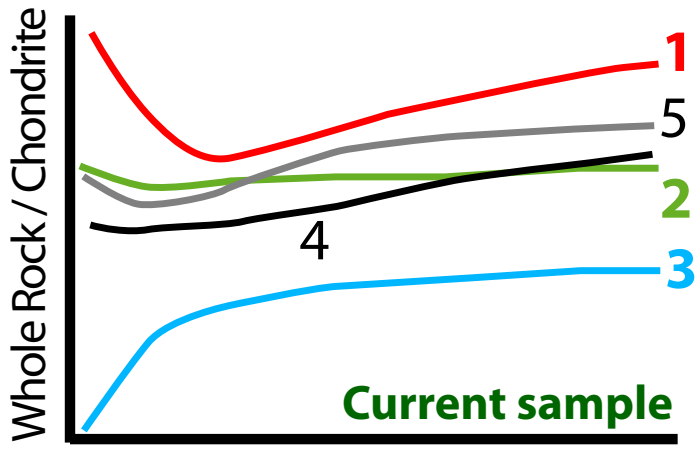

Rare Earth Elements 


\section{$\mathbf{a}$}

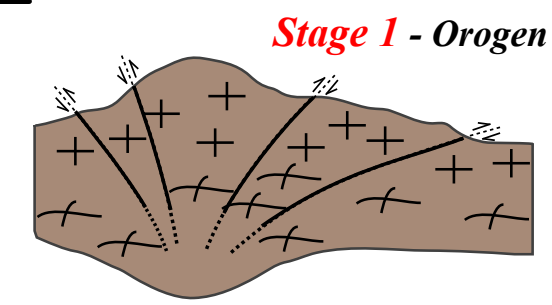

Stage 2 - Late orogenic exhumation

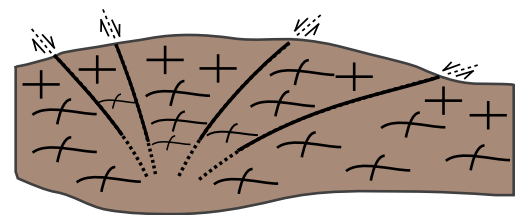

Mantle

Figure 13

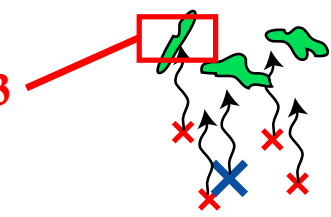

Stage 4

Post orogenic initiation of thermal anomaly or mantle plume

\section{POST OROGENIC CYCLE}

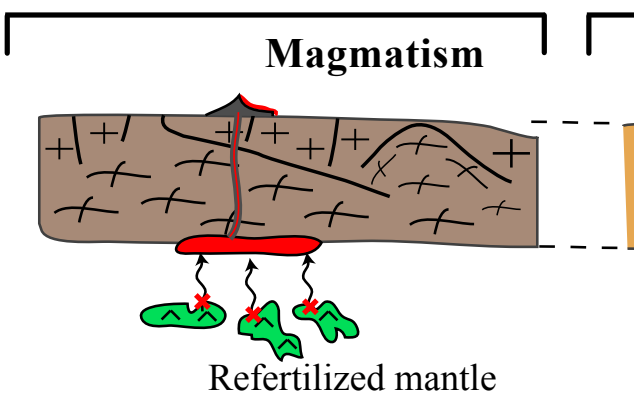

Refertilized mantle

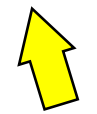

\section{NO FORMER OROGENIC CYCLE}

No magmatism
Initiation of thermal anomaly
Stage 3 - Continuing exhumation and $P$-T reequilibration

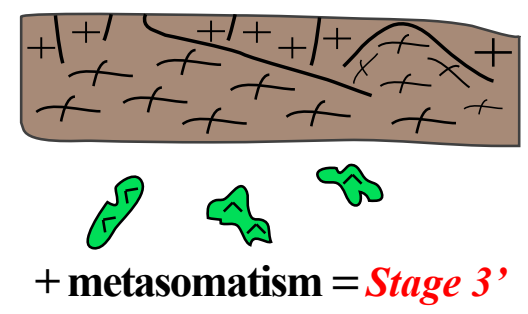

Refertilized mantle (high concentration of pyroxenites)
+ Upper crust

+ Lower crust

$\times$ Pyroxenites mantle source

$x \quad$ Mantle partial melting

$\uparrow$ Melt migration

$\approx$ Pyroxenites crystallization

त Studied pyroxenites 

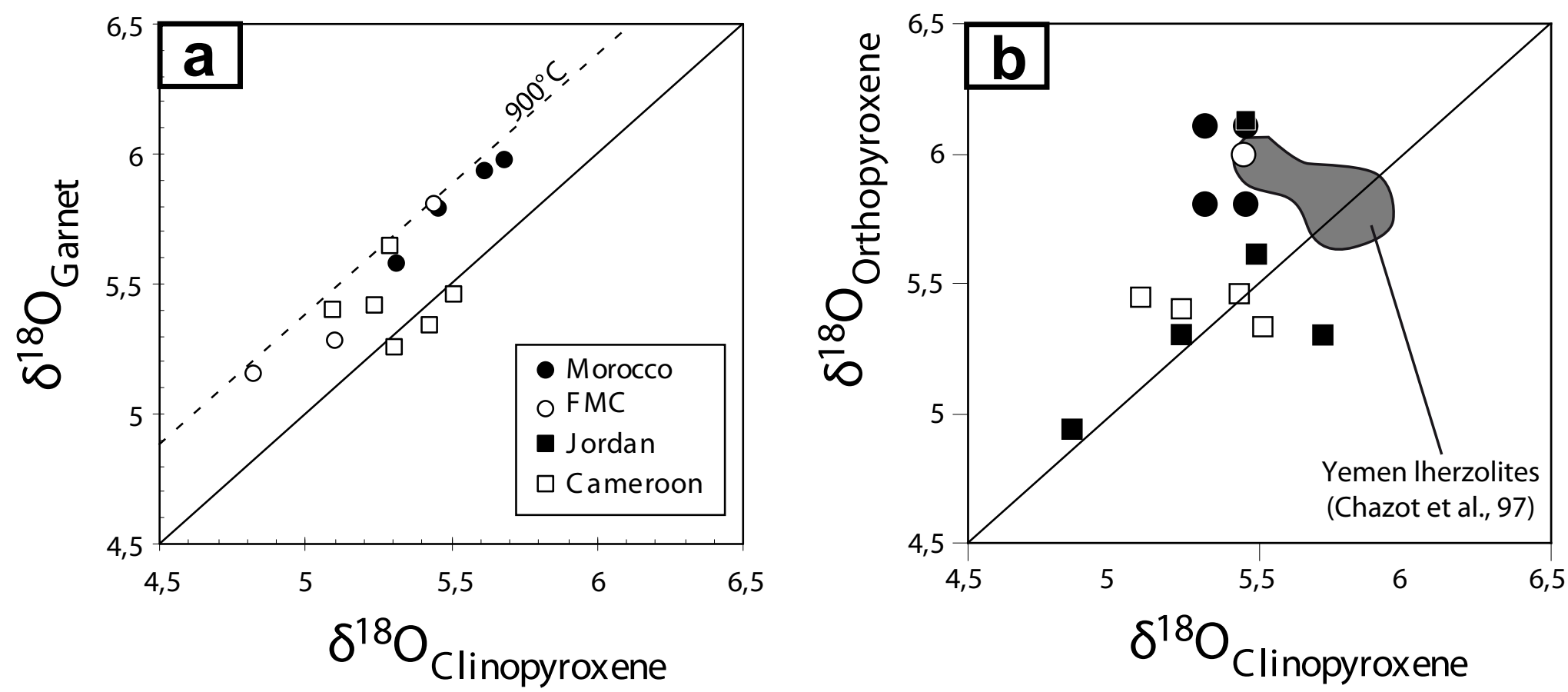

France et al., Fig. S1 